\title{
Optimization of Chromium and Copper Ions Uptake by Aspergillus Terreus Strain Using Different Techniques
}

\author{
Khadiga A. A. Abou-Taleb ${ }^{1 *}$, Wedad E. Eweda ${ }^{1}$ and H. I. Mira ${ }^{2}$ \\ ${ }^{1}$ Department of Agricultural Microbiology, Faculty of Agriculture, Ain Shams University, Shoubra El-Kheima, \\ Cairo, Egypt. \\ ${ }^{2}$ Nuclear Materials Authority, Cairo, Egypt. \\ Email: khadija_aboutaleb@agr.asu.edu.eg
}

\begin{abstract}
The heavy metal resistant isolate FR1 was identified using phenotypic and genotypic characteristics; it was classified as Aspergillus terreus strain. Lactose and yeast extract were favorable for $\mathrm{Cr}^{+5}$ and $\mathrm{Cu}^{+2}$ ions biosorption by tested strain after 6 days incubation period. The positive significant variables (yeast extract, temperature \& inoculum size or lactose, yeast extract, temperature \& incubation period) affecting heavy metals biosorption using Placket-Burman statistical experimental design in presence $\mathrm{Cr}^{+5}$ and $\mathrm{Cu}^{+2}$ were further optimized by using response surface methodology. It was found that the highest growth of strain in presence of $\mathrm{Cr}^{+5}$ and $\mathrm{Cu}^{+2}\left(4.31\right.$ and $\left.3.69 \mathrm{gL}^{-1}\right)$ were attained at $0.15 \%$ yeast extract, $2 \%$ inoculum size \& incubated at $28^{\circ} \mathrm{C}$ and $0.65 \%$ lactose, $0.15 \%$ yeast extract, an incubation temperature of $30{ }^{\circ} \mathrm{C}$ and 8 days incubation period, respectively. There is no significant difference between absorption and adsorption mechanism for reduction of heavy metals from Egyptian phosphatic fertilizer sample.
\end{abstract}

Keywords: Biosorption; Aspergillus terreus; Placket-Burman design; response surface methodology; $\mathrm{Cr}^{+5}$ and $\mathrm{Cu}^{+2}$ ions.

\section{Introduction}

Metals are toxic to all biological systems from microbial to plant and animal, with microorganisms affected more so than other systems, due, in part, to their small size and direct involvement with their environment [1-2]. Metal toxicity negatively impacts all cellular processes, influencing metabolism, genetic fidelity and growth. Loss of bacterial populations in metal-contaminated soils impacts elemental cycling, organic remediation efforts, plant growth and soil structure. Human activities such as industrial production, mining, agriculture and transportation release a high amount of heavy metals to the biosphere. The primary sources of metal pollution are the burning of fossil fuels, smelting of metal like ores, municipal wastes, fertilizers, pesticides and sewage [3-5]. Heavy metals are accumulated into soils and plants and could have a negative influence on physiological activities of plants and cause for the reductions in plant growth, dry matter accumulation and yield [6]. Vegetables are vital to the human diet and in particular provide the well-known trace elements and heavy metals. Minor or trace elements are essential for good health if they come from an organic or plant source. In contrast, if they come from an inorganic or metallic source, they become toxic. The processes of plant growth depend on the cycle of nutrients including trace elements, from soil to plant. Vegetables, especially leafy vegetables, accumulate higher amounts of heavy metals because they absorb these metals in their leaves [7]. They showed that the $\mathrm{Cd}, \mathrm{Pb}$ and $\mathrm{Hg}$ contents of the soils had increased significantly with the addition of fertilizer by the 14-60\% over the control soil. Root and shoot, accumulation of the heavy metals by the plants had also increased after fertilizer application, with $\mathrm{Cd}$ and $\mathrm{Pb}$ being particularly high. From among the metals, $\mathrm{Cd}$ showed the highest transfer ratio from soil to plant tissues [8]. The rate at which heavy metals are accumulated in the soil depends on the physiochemical properties of the soil and the relative efficiency of crops to remove the metals from the soil. Heavy metals accumulated in cultivated soils can be transferred to humans through various exposure pathways causing adverse effects on human health [9]. Bioremediation can be separated into two categories, biosorption and bioaccumulation. Biosorption is a passive adsorption mechanism that is fast and reversible [10]. The metals are retained by means of physicochemical interaction (e.g., ion exchange, adsorption, complexation, precipitation, and crystallization) between the metal and the 
functional groups present on the cell surface [11]. Both living and dead biomass can occur for biosorption because it is independent of cell metabolism. On the other hand, bioaccumulation includes both intra- and extracellular processes where passive uptake plays only a limited and not very well-defined role, therefore, living biomass can only occur for bioaccumulation [12]. The complex structure of microorganisms implies that there are many ways for the metal to be taken up by the microbial cell. The biosorption mechanisms are various and are not fully understood. They may be classified according to various criteria [13]. I. According to the dependence on the cell's metabolism, biosorption mechanisms can be divided into: a. Active metabolism-dependent and b. passive metabolism-independent. II. According to the location where the metal removed from solution is found, biosorption can be classified as: a. Extra- cellular accumulation/ precipitation, b. Cell surface sorption/ precipitation and c. Intracellular accumulation. The filamentous fungi, Aspergillus sp. and Rhizopus sp., Fusarium sp., Penicillium sp. and Cephalosporium sp. isolated from metal-contaminated agricultural soil were capability to biosorption of different heavy metals such as $\mathrm{Cu}, \mathrm{Cd}$, $\mathrm{Pb}$ and $\mathrm{Cr}$ [14-16]. The $\mathrm{pH}$ value of the solution is reported to influence the composition of the binding site on the surface of biomass as well as the chemical state of metal in solution [17]. The most of the microbial surfaces are negatively charged due to the ionization of functional group thereby contributing to metal binding [18]. The cell surface copper binding sites and the availability of copper in the solution are influenced by $\mathrm{pH}$. Little biosorption of $\mathrm{Cu}(\mathrm{II})$ ions was observed at low $\mathrm{pH}$ due to the competition between hydrogen ions and copper ions on the biosorption active sites. The increase of $\mathrm{pH}$ resulted in an increased negative charge on the surface of the cell, which favored electrochemical attraction and adsorption of copper [19].

The present study aimed to screen and evaluate the factors affecting on the reduction of heavy metal ions by the identified fungal isolate using $18 \mathrm{~S}$ rRNA sequence, and applied this strain for removal of some heavy metal from Egyptian phosphate fertilizer sample.

\section{$2 \quad$ Materials and Methods}

\subsection{Microorganism and Molecular Identification}

Aspergillus sp. FR1 was used in the present investigation as heavy metals removing isolate, which was previously isolated from Egyptian phosphatic fertilizers, and identified based on phenotypic characterization by Abd El Hameed et al [20]. The fungal culture slants were maintained at $5{ }^{\circ} \mathrm{C}$ on potato-dextrose agar (PDA) [21] with the following composition $\left(\mathrm{gL}^{-1}\right)$ : potatoes, 200; dextrose, 20; agar, 20 and adjusted to $\mathrm{pH} 5.0$ after incubation at $30^{\circ} \mathrm{C}$ for $24-48 \mathrm{~h}$. The fungal genomic DNA was extracted from the culture in PDA medium by using Gene Jet genomic DNA purification Kit (Thermo) according to the manufacturer's instructions. Amplification of $18 \mathrm{~S}$ rDNA by PCR was done using universal fungi primer forward (ITS1) F (5`- TCC GTA GGT GAA CCT GCG G -3’) and reverse (ITS4) R (5` TCC TCC GCT TAT TGA TAT GC $-3^{\prime}$ ) described by [22]. Amplification was carried out in a $50 \mu \mathrm{l}$ reaction volume. The thermal cycle (PCR) steps were applied as follows; $10 \mathrm{~min}$ initial denaturation at $95^{\circ} \mathrm{C}$, followed by 40 cycles of $15 \mathrm{sec}$ denaturation at $95^{\circ} \mathrm{C}, 30 \mathrm{sec}$ primer annealing at $60^{\circ} \mathrm{C}, 30 \mathrm{sec}$ extension at $72^{\circ} \mathrm{C}$ and a final 10 min extension at $72^{\circ} \mathrm{C}$. The amplified DNA fragment was separated on $1.2 \%(\mathrm{w} / \mathrm{v})$ agarose gel electrophoresis, eluted and purified using the Qiaquick gel extraction kit (Qiagen, Germany) following the manufacturer's protocol [23]. The purified PCR product was sequenced using the ABI 3730xl DNA sequencer (GATC Company). Sequence data of partial 16S rDNA was aligned and analyzed for finding the closest homologous microbes. The unknown query $18 \mathrm{~S}$ rRNA nucleotide sequence was compared to nucleotide data bases using BLASTN program that is available from the National Center for Biotechnology Information [24] and retrieved from Gene Bank database. Then multiple sequence alignment was developed for these homologous sequences using the algorithm described in CLUSTAL Omega. A phylogenetic tree was then drawn using the Neighbor joining method.

\subsection{Heavy Metals Biosorption by the Tested Strain}

Batch experiments were performed in $250 \mathrm{ml}$ plugged Erlenmeyer flasks, each containing $100 \mathrm{ml}$ sterile modified Czapek Dox broth medium [20] with the following composition $\left(\mathrm{gL}^{-1}\right)$ : Sucrose, 30; $\mathrm{NaNO}_{3}, 3$; $\mathrm{K}_{2} \mathrm{HPO}_{4}, 1 ; \mathrm{KCl}, 0.5 ; \mathrm{FeSO}_{4}, 0.1 ; \mathrm{MgSO}_{4} \cdot 7 \mathrm{H}_{2} \mathrm{O}, 0.5$; Heavy metal ion $\left(\mathrm{Cr}^{+5}\right.$ or $\left.\mathrm{Cu}^{+2}\right), 150 \mathrm{ppm}$ and adjusted 
to $\mathrm{pH}$ 5.0. *The above medium composition was modified by addition of different metal ions to heavy metals biosorption and inoculated with $2 \%$ of standard inoculum for the tested fungal strain which was incubated at $30^{\circ} \mathrm{C}$ on rotary shaker at $150 \mathrm{rpm}$ for 6 days. The cultural medium was filtrated in order to determine the growth. All the experiments were carried out at least in triplicate.

\subsection{Nutritional Factors}

This experiment was performed to study the effect of different carbon sources on heavy metals biosorption by tested fungus. Therefore, the appropriate carbon source was selected by replacing the original carbon source of the used medium (sucrose) with equivalent carbon amount of each of the tested carbon source (glucose, sucrose, fructose and lactose) to eliminate errors which may occur as a result of differences in carbon concentrations in each source. The previous procedure of propagation was used. To detect the adequate nitrogen source for heavy metal removal by selected strain, the prescribed nitrogen source of the fermentation medium $\left(\mathrm{NaNO}_{3}\right)$ was replaced by equivalent nitrogen amount of each of the tested organic nitrogen source (beef extract, peptone, yeast extract and tryptone) and inorganic nitrogen source $\left(\left(\mathrm{NH}_{4}\right)_{2} \mathrm{SO}_{4}, \mathrm{NaNO}_{3}\right.$ and urea). At the end of incubation period, the growth of fungal cultures was filtrated and determined as cell dry weight.

\subsection{Statistical Experimental Designs for Evaluation of the Factors Affecting Growth of Tested Strain (Biosorption of Heavy Metals)}

2.4.1 Screening of Most Significant Fermentation Parameters Using Plackett-Burman Design

The most heavy metal $\left(\mathrm{Cr}^{+5}\right.$ or $\left.\mathrm{Cu}^{+2}\right)$ removal by Plackett-Burman design. Plackett-Burman design using statistical software package Design-Expert software 9.0.0 (Stat-Ease, Inc., Minneapolis, MN 55413, USA 2014), was used to evaluate the relative importance of physical and nutritional factors for heavy metal absorption by A. terreus FR1. A total of 7 (n) variables including 2 nutritional (lactose concentration as a sole carbon source and yeast extract concentration as a nitrogen source) and 5 environmental factors ( $\mathrm{pH}$, temperature, inoculum size, incubation period and agitation speed) with 4 dummy variables (which will provide an adequate estimate of the error) were studied in $11(n+1)$ experiments as shown in Table 1 for tested fungi [25]. All the trials were performed in duplicate and the average of observation was used as the response of the design. Each variable represented at 2 levels, high and low, was denoted by $(+)$ and $(-)$ signs, respectively. Each row represented a trial run and each column represented an independent variable.

Table 1. Plackett-Burman experimental design matrix and the actual values of cell dry weight in presence of $\mathrm{Cr}^{+5}$ and $\mathrm{Cu}^{+2}$ by $A$. terreus FR1.

\begin{tabular}{|c|c|c|c|c|c|c|c|c|c|c|c|c|c|}
\hline \multirow{2}{*}{$\begin{array}{l}\text { Run } \\
\text { no. }\end{array}$} & \multicolumn{11}{|c|}{ Variables } & \multicolumn{2}{|c|}{ Cell dry weight $\left(\mathrm{gL}^{-1}\right)$} \\
\hline & $\mathrm{A}$ & $\mathrm{B}$ & $\mathrm{C}$ & $\mathrm{D}$ & $E$ & $F$ & $G$ & $\mathrm{H}$ & $\mathrm{J}$ & $\mathrm{K}$ & $L$ & $\mathrm{Cr}^{+5}$ & $\mathrm{Cu}^{+2}$ \\
\hline 1 & +1 & -1 & +1 & +1 & -1 & +1 & +1 & +1 & -1 & -1 & -1 & 0.595 & 0.532 \\
\hline 2 & +1 & +1 & +1 & -1 & -1 & -1 & +1 & -1 & +1 & +1 & -1 & 0.574 & 0.509 \\
\hline 3 & -1 & -1 & +1 & -1 & +1 & +1 & -1 & +1 & +1 & +1 & -1 & 0.816 & 0.695 \\
\hline 4 & +1 & -1 & +1 & +1 & +1 & -1 & -1 & -1 & +1 & -1 & +1 & 0.855 & 0.414 \\
\hline 5 & -1 & +1 & +1 & -1 & +1 & +1 & +1 & -1 & -1 & -1 & +1 & 0.502 & 0.610 \\
\hline 6 & +1 & +1 & -1 & -1 & -1 & +1 & -1 & +1 & +1 & -1 & +1 & 0.507 & 0.451 \\
\hline 7 & -1 & -1 & -1 & -1 & -1 & -1 & -1 & -1 & -1 & -1 & -1 & 0.866 & 0.721 \\
\hline 8 & +1 & +1 & -1 & +1 & +1 & +1 & -1 & -1 & -1 & +1 & -1 & 0.369 & 0.199 \\
\hline 9 & -1 & +1 & -1 & +1 & +1 & -1 & +1 & +1 & +1 & -1 & -1 & 0.431 & 0.531 \\
\hline 10 & -1 & -1 & -1 & +1 & -1 & +1 & +1 & -1 & +1 & +1 & +1 & 0.467 & 0.862 \\
\hline 11 & -1 & +1 & +1 & +1 & -1 & -1 & -1 & +1 & -1 & +1 & +1 & 0.440 & 0.318 \\
\hline 12 & +1 & -1 & -1 & -1 & +1 & -1 & +1 & +1 & -1 & +1 & +1 & 0.879 & 0.771 \\
\hline \multicolumn{8}{|c|}{ Variables } & \multicolumn{6}{|c|}{ Real levels } \\
\hline \multicolumn{8}{|c|}{ Symbol } & \multicolumn{4}{|c|}{-1} & \multicolumn{2}{|l|}{1} \\
\hline \multicolumn{5}{|c|}{ Lactose concentration (\%) } & \multicolumn{3}{|c|}{. } & \multicolumn{4}{|c|}{0.85} & \multicolumn{2}{|c|}{0.9} \\
\hline \multicolumn{5}{|c|}{ Yeast extract concentration $(\%)$} & \multicolumn{3}{|c|}{ B } & \multicolumn{4}{|c|}{0.23} & \multicolumn{2}{|c|}{0.25} \\
\hline \multicolumn{5}{|l|}{$\mathrm{pH}$} & \multirow{2}{*}{\multicolumn{3}{|c|}{$\begin{array}{l}\text { C } \\
\text { D }\end{array}$}} & \multicolumn{4}{|c|}{6} & \multicolumn{2}{|l|}{7} \\
\hline \multicolumn{5}{|c|}{ Temperature $\left({ }^{\circ} \mathrm{C}\right)$} & & & & \multicolumn{4}{|c|}{28} & \multirow{2}{*}{\multicolumn{2}{|c|}{30}} \\
\hline \multicolumn{5}{|c|}{ Agitation speed (rpm) } & \multicolumn{3}{|c|}{$\begin{array}{l}\mathrm{D} \\
\mathrm{E}\end{array}$} & \multicolumn{4}{|c|}{ static } & & \\
\hline \multicolumn{5}{|c|}{ Inoculum size (\%) } & \multicolumn{3}{|c|}{$\mathrm{F}$} & & 2 & & & 3 & \\
\hline Incuba & ion $\mathrm{p}$ & od $(\mathrm{h}$ & & & & G & & & 6 & & & 7 & \\
\hline Dumm & & & & & & $\mathrm{H}$ & & & - & & & - & \\
\hline Dumm & & & & & & J & & & - & & & - & \\
\hline Dumm & & & & & & $\mathrm{k}$ & & & - & & & - & \\
\hline Dumm & & & & & & L & & & - & & & - & \\
\hline
\end{tabular}

$\mathrm{A}-\mathrm{G}=$ Nutritional and physical variables, $\mathrm{H}-\mathrm{L}=$ Dummy variables, $-1=$ low level of the variable $\&+1=$ high level of the variable. 
Plackett-Burman experimental design is based on first order model, which was determined by the following Eq. (1):

$$
Y=B_{0}+\Sigma B_{i} x_{i}
$$

where $\mathrm{Y}$ is the response (Cell dry weight), $\mathrm{B}_{0}$ is model intercept and $\mathrm{B}_{\mathrm{i}}$ was variables estimates. Effect of each variable was determined by the following equation:

$$
E\left(X_{i}\right)=2\left({ }_{+} \Sigma M_{i}-\Sigma M_{i}^{-}\right) / N
$$

where $\mathrm{E}\left(\mathrm{X}_{\mathrm{i}}\right)$ is tested variable effect and $\mathrm{M}_{i_{+}}$and $\mathrm{M}_{\mathrm{i}_{-}}$represent heavy metals removal from trials when variables $\left(\mathrm{X}_{\mathrm{i}}\right)$ measured were presently at high and low concentrations, respectively and $\mathrm{N}$ is the number of trials in Eq. (2).

Standard error (SE) of the concentration effect was square root of the variance of an effect, and the significance level (p-value) of each concentration effect was determined using Student's t-test t $\left(\mathrm{X}_{\mathrm{i}}\right)$ in Eq. (3).

where $\mathrm{E}\left(\mathrm{X}_{\mathrm{i}}\right)$ is variable $\mathrm{X}_{\mathrm{i}}$ effect.

$$
t\left(X_{i}\right)=E\left(X_{i}\right) / S E
$$

\subsubsection{Central Composite Design (CCD) and Response Surface Methodology (RSM)}

After identifying the significant variables for biosorption of both tested heavy metals by A. terreus FR1 through a Plackett-Burman design, a central composite design (CCD) was adopted to optimize the major variables. The three or four selected independent variables were studied at 3 different levels (as $-1,0$ and +1 ), and sets of 20 or 30 experiments (batch experiments) were carried out in presence of $\mathrm{Cr}^{+5} \mathrm{or}^{\mathrm{Cu}} \mathrm{u}^{+2}$ for tested fungi, respectively (Tables 2 and 3). All variables were taken at a central coded value of zero. The minimum and maximum ranges of variables investigated are listed in these tables.

\begin{tabular}{|c|c|c|c|c|c|c|}
\hline \multirow[t]{2}{*}{ Run no. } & \multicolumn{3}{|c|}{ Variables } & \multicolumn{3}{|c|}{$\begin{array}{l}\text { Cell dry weight }\left(\mathrm{gL}^{-1}\right) \\
\text { in presence of } \mathrm{Cr}^{+5}\end{array}$} \\
\hline & A & B & C & \multicolumn{2}{|c|}{ Actual } & Predict \\
\hline 1 & -1 & -1 & +1 & \multicolumn{2}{|c|}{0.12} & 2.28 \\
\hline 2 & $\mathbf{0}$ & $\mathbf{0}$ & $\mathbf{0}$ & \multicolumn{2}{|c|}{4.09} & 2.89 \\
\hline 3 & $\mathbf{0}$ & $\mathbf{0}$ & $\mathbf{0}$ & \multicolumn{2}{|c|}{2.35} & 2.89 \\
\hline 4 & +1 & +1 & $-\mathbf{1}$ & \multicolumn{2}{|c|}{0.40} & 0.18 \\
\hline 5 & $\mathbf{0}$ & +1 & $\mathbf{0}$ & \multicolumn{2}{|c|}{0.38} & 1.20 \\
\hline 6 & -1 & $\mathbf{0}$ & $\mathbf{0}$ & \multicolumn{2}{|c|}{4.31} & 4.07 \\
\hline 7 & -1 & +1 & +1 & \multicolumn{2}{|c|}{3.44} & 3.42 \\
\hline 8 & $\mathbf{0}$ & $\mathbf{0}$ & $\mathbf{0}$ & \multicolumn{2}{|c|}{2.30} & 2.89 \\
\hline 9 & +1 & -1 & +1 & \multicolumn{2}{|c|}{3.24} & 3.46 \\
\hline 10 & -1 & -1 & $\mathbf{0}$ & \multicolumn{2}{|c|}{2.05} & 1.33 \\
\hline 11 & $\mathbf{0}$ & $\mathbf{0}$ & $\mathbf{0}$ & \multicolumn{2}{|c|}{3.31} & 2.89 \\
\hline 12 & $\mathbf{0}$ & $\mathbf{0}$ & -1 & \multicolumn{2}{|c|}{3.33} & 3.39 \\
\hline 13 & $\mathbf{0}$ & $\mathbf{0}$ & $\mathbf{0}$ & \multicolumn{2}{|c|}{3.36} & 2.89 \\
\hline 14 & +1 & -1 & -1 & \multicolumn{2}{|c|}{1.53} & 1.56 \\
\hline 15 & -1 & -1 & -1 & \multicolumn{2}{|c|}{3.43} & 3.74 \\
\hline 16 & $\mathbf{0}$ & $\mathbf{0}$ & $\mathbf{0}$ & \multicolumn{2}{|c|}{2.10} & 2.89 \\
\hline 17 & $-\mathbf{1}$ & +1 & -1 & \multicolumn{2}{|c|}{4.03} & 3.81 \\
\hline 18 & +1 & +1 & +1 & \multicolumn{2}{|c|}{3.51} & 3.15 \\
\hline 19 & +1 & $\mathbf{0}$ & $\mathbf{0}$ & \multicolumn{2}{|c|}{2.36} & 2.70 \\
\hline 20 & $\mathbf{0}$ & o & -1 & \multicolumn{2}{|c|}{3.36} & 3.39 \\
\hline \multirow{2}{*}{ Variables } & \multirow{2}{*}{\multicolumn{3}{|c|}{ Symbol }} & \multicolumn{3}{|c|}{ Real levels } \\
\hline & & & & -1 & $\mathbf{0}$ & +1 \\
\hline Yeast extract conc. (\%) & & A & & 0.15 & 0.19 & 0.23 \\
\hline Temperature $\left({ }^{\circ} \mathrm{C}\right)$ & & B & & 25 & 28 & 30 \\
\hline Inoculum size (\%) & & C & & 1 & 2 & 3 \\
\hline
\end{tabular}

Table 2. Central composite design matrix (CCD) of independent variables used in RSM studies and removal $\mathrm{Cr}^{+5}$ by A. terreus FR1.

$\mathrm{A}-\mathrm{C}=$ Nutritional and physical variables, $-1=$ low level of the variable, $0=$ medium level of the variable $\&+1=$ high level of the variable. 
The statistical software package Design-Expert software 9.0.0 (Stat-Ease, Inc., Minneapolis, MN 55413, USA 2014), was used to analyze the experimental data. The optimal values of the independent variables that gave theoretical maximum response in Eq. 4 were obtained by maximizing the equation within a definite boundary condition. Biosorption were taken as response (Y) and a multiple regression analysis of the data was carried out for obtaining an empirical model that relates the response measured to the independent variables. The relationship of the independent variables and the response was calculated by the second order polynomial equation (Eq. 4).

$$
Y_{i}=b_{0}+b_{1} X_{1}+b_{2} X_{2}+b_{3} X_{3}+b_{11} X_{1}^{2+} b_{22} X_{2}^{2}+b_{33} X_{3}^{2}+b_{12} X_{1} X_{2}+b_{23} X_{2} X_{3}+b_{13} X_{1} X_{3}
$$

where $Y_{i}$ is the predicted response, $X_{1}, X_{2}, X_{3}$ are independent variables, $b_{0}$, is the offset term, $b_{1}, b_{2}, b_{3}$ are linear effects, $b_{11}, b_{22}, b_{33}$ are squared effects and $b_{12}, b_{23}, b_{13}$ are interaction terms.

\subsection{Preparation of Dead Fungal Biomass}

The biomass of the A. terreus FR1 was prepared in PDA medium. After $48 \mathrm{~h}$, the fungal biomass was separated from medium using filtered through Whattman filter paper. The biomass was dried by the process of drying on hot oven in order to absorb the moisture content at temperature of $120^{\circ} \mathrm{C}$ for about 3-4 days and was utilized in further biosorption studies [26].

Table 3. Central composite design matrix (CCD) of independent variables used in RSM studies and removal $\mathrm{Cu}^{+2}$ by A. terreus FR1.

\begin{tabular}{|c|c|c|c|c|c|c|}
\hline \multirow{3}{*}{ Run no. } & \multirow{2}{*}{\multicolumn{4}{|c|}{ Variables }} & \multicolumn{2}{|c|}{ Cell dry weight $\left(\mathrm{gl}^{-1}\right)$ ir } \\
\hline & & & & & presence of & \multirow{2}{*}{$\begin{array}{l}\mathrm{Cu}^{+2} \\
\text { Predicted }\end{array}$} \\
\hline & A & B & C & D & Actual & \\
\hline 1 & -1 & +1 & $\mathbf{o}$ & -1 & 2.91 & 2.83 \\
\hline 2 & $\mathbf{0}$ & $\mathbf{0}$ & +1 & $\mathbf{0}$ & 2.99 & 2.99 \\
\hline 3 & +1 & $\mathbf{0}$ & +1 & $\mathbf{0}$ & 2.75 & 2.75 \\
\hline 4 & $\mathbf{0}$ & $\mathbf{0}$ & +1 & $\mathbf{0}$ & 2.99 & 2.99 \\
\hline 5 & $\mathbf{0}$ & $\mathbf{0}$ & +1 & $\mathbf{0}$ & 2.99 & 2.99 \\
\hline 6 & $\mathbf{0}$ & $\mathbf{0}$ & +1 & $\mathbf{0}$ & 2.99 & 2.99 \\
\hline 7 & $\mathbf{0}$ & $\mathbf{1}$ & +1 & $\mathbf{0}$ & 2.29 & 2.17 \\
\hline 8 & +1 & -1 & -1 & +1 & 3.19 & 3.20 \\
\hline 9 & -1 & $\mathbf{1}$ & -1 & -1 & 3.42 & 3.42 \\
\hline 10 & $\mathbf{0}$ & $\mathbf{o}$ & +1 & +1 & 3.17 & 3.17 \\
\hline 11 & -1 & 1 & -1 & +1 & 3.09 & 3.19 \\
\hline 12 & $\mathbf{0}$ & $\mathbf{0}$ & $\mathbf{0}$ & $\mathbf{0}$ & 3.03 & 3.03 \\
\hline 13 & +1 & $\mathbf{1}$ & $-\mathbf{1}$ & +1 & $\mathbf{3 . 3 3}$ & 3.33 \\
\hline 14 & -1 & -1 & $\mathbf{o}$ & $-\mathbf{1}$ & 3.45 & 3.51 \\
\hline 15 & +1 & 1 & -1 & $-\mathbf{1}$ & 3.11 & 3.06 \\
\hline 16 & +1 & -1 & -1 & $-\mathbf{1}$ & 2.88 & 3.04 \\
\hline 17 & $\mathbf{0}$ & $\mathbf{0}$ & +1 & $\mathbf{0}$ & 2.99 & 2.99 \\
\hline 18 & -1 & -1 & $\mathbf{0}$ & +1 & 3.44 & 3.41 \\
\hline 19 & $\mathbf{0}$ & -1 & +1 & $\mathbf{0}$ & 3.69 & 3.80 \\
\hline 20 & $\mathbf{0}$ & $\mathbf{0}$ & +1 & $\mathbf{o}$ & 2.99 & 2.99 \\
\hline 21 & +1 & 1 & +1 & -1 & 1.29 & 1.48 \\
\hline 22 & $\mathbf{0}$ & $\mathbf{0}$ & +1 & -1 & 2.63 & 2.63 \\
\hline 23 & $\mathbf{0}$ & $\mathbf{o}$ & +1 & $\mathbf{0}$ & 2.98 & 2.99 \\
\hline 24 & -1 & -1 & -1 & +1 & 2.70 & 2.60 \\
\hline 25 & +1 & $\mathbf{1}$ & $\mathbf{o}$ & +1 & 2.69 & 2.62 \\
\hline 26 & +1 & -1 & $\mathbf{o}$ & $-\mathbf{1}$ & 3.56 & 3.26 \\
\hline 27 & $-\mathbf{1}$ & +1 & $\mathbf{o}$ & +1 & 2.80 & 2.84 \\
\hline 28 & -1 & +1 & -1 & $-\mathbf{1}$ & 2.93 & 2.94 \\
\hline 29 & $\mathbf{0}$ & $\mathbf{0}$ & +1 & $\mathbf{0}$ & 2.99 & 2.99 \\
\hline 30 & +1 & -1 & o & +1 & 3.59 & 3.66 \\
\hline \multirow{2}{*}{\multicolumn{2}{|c|}{ Variables }} & \multirow{2}{*}{ Symbol } & \multicolumn{4}{|c|}{ Real levels } \\
\hline & & & -1 & & 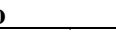 & +1 \\
\hline \multirow{2}{*}{\multicolumn{2}{|c|}{$\begin{array}{l}\text { Lactose conc. (\%) } \\
\text { Yeast extract }\end{array}$}} & A & 0.45 & \multicolumn{2}{|c|}{0.65} & 0.85 \\
\hline & & B & 0.15 & & 19 & 0.23 \\
\hline & C & 25 & \multicolumn{2}{|c|}{28} & 30 \\
\hline \multicolumn{2}{|c|}{$\begin{array}{l}\text { Temperature }\left({ }^{\circ} \mathrm{C}\right) \\
\text { Incubation period }\end{array}$} & D & 7 & \multicolumn{2}{|c|}{8} & 9 \\
\hline
\end{tabular}

$\mathrm{A}-\mathrm{D}=$ Nutritional and physical variables, $-1=$ low level of the variable, $0=$ medium level of the variable $\&+1=$ high level of the variable. 


\subsection{Application on Phosphate Fertilizer Sample by Using Heavy Metal Resistant Fungi}

Living or dried dead biomasses of A. terreus FR1 were inoculated into $100 \mathrm{ml}$ liquid medium containing tri-phosphate fertilizer sample or plates containing $5 \mathrm{~g}$ phosphate fertilizer sample. The metal ions residual in samples were determined. The experiment was done in duplicate and the amount of metallic ion biosorbed per gram of biomass (q) and the efficiency of biosorption (E) were calculated.

\subsection{Analytical Procedures}

Determination of fungal growth (cell dry weight) was performed by filtrating using filter paper No.1, washing twice, and drying at $70^{\circ} \mathrm{C}$ until constant weight. The residual heavy metals in filtrated fungal culture (supernatant) and tri-phosphate fertilizer sample were determined using inductively coupled plasma-mass spectrometer (ICP-MS) atomic absorption spectrophotometer, CENTRAL IAB., FAC. OF AGRIC., AIN SHAMS UNIV., EGYPT.

\subsection{Parameters Calculation}

The specific growth rate $(\mu)$, doubling time $\left(t_{d}\right)$, Multiplication rate $(M R)$ and number of generations were calculated using the following equations [27-29]. The following formulas were used to calculate these parameters: specific growth rate $(\mu)\left(h^{-1}\right)=\left(\ln X-\ln X_{0}\right)\left(t-t_{0}\right)^{-1}$, doubling time $\left(t_{d}\right)(h)=\ln (2)(\mu)^{-1}$, multiplication rate $(M R)=1\left(t_{d}\right)^{-1}$ and number of generation $(N)=\left(t-t_{0}\right)\left(t_{d}\right)^{-1}$

where:

$\mathrm{X}=$ Amount of growth after $\mathrm{t}$ time $(\mathrm{t})$.

$\mathrm{X} 0=$ Amount of growth at the beginning time $\left(\mathrm{t}_{0}\right)$.

Specific heavy metal uptake (The amount of metallic ion biosorbed per gram of biomass (q)) was calculated using the following equation [30].

$$
\left(\frac{\mathrm{Ci}-\mathrm{Cf}}{\mathrm{m}}\right) \times \mathrm{V}
$$

where, $\mathrm{Ci}=$ initial concentration of the metallic ions $\left(\mathrm{mg} \mathrm{L}^{-1}\right) ; \mathrm{Cf}=$ final concentration of metallic ions $(\mathrm{mg}$ $\left.\mathrm{L}^{-1}\right) ; \mathrm{m}=$ dried mass of the biosorbent in the reaction mixture $(\mathrm{g})$ and $\mathrm{V}=$ volume of reaction mixture $(\mathrm{ml})$.

Efficiency of biosorption (E) was calculated using following equations [31].

$$
\mathrm{E}=\left(\frac{\mathrm{Ci}-\mathrm{Cf}}{\mathrm{Ci}}\right) \times 100
$$

where, $\mathrm{Ci}=$ initial concentration of the metallic ions $\left(\mathrm{mg} \mathrm{L}^{-1}\right)$ and $\mathrm{Cf}=$ final concentration of metallic ions $\left(\mathrm{mg} \mathrm{L}^{-1}\right)$.

\section{$2.9 \quad$ Statistical Analysis}

The collected data were statistically analyzed using IBM® SPSS® Statistics software [32].

\section{$3 \quad$ Results and Discussion}

\subsection{Identification of the Most Efficient Heavy Metals Removing Isolates}

According to the morphological characteristics (microscopic shape and color of conidia) of fungal isolate FR1, which was subjected to the preliminary classification to be the genus Aspergillus according to Barnett and Hunter [33], these isolates showed granular colonies on Czapek's Dox agar. The colonies were flat, with radial grooves. Microscopic observation of the fungal isolate indicated erect conidiophores with globose vesicles bearing chains of conidia (Fig. 1a). 

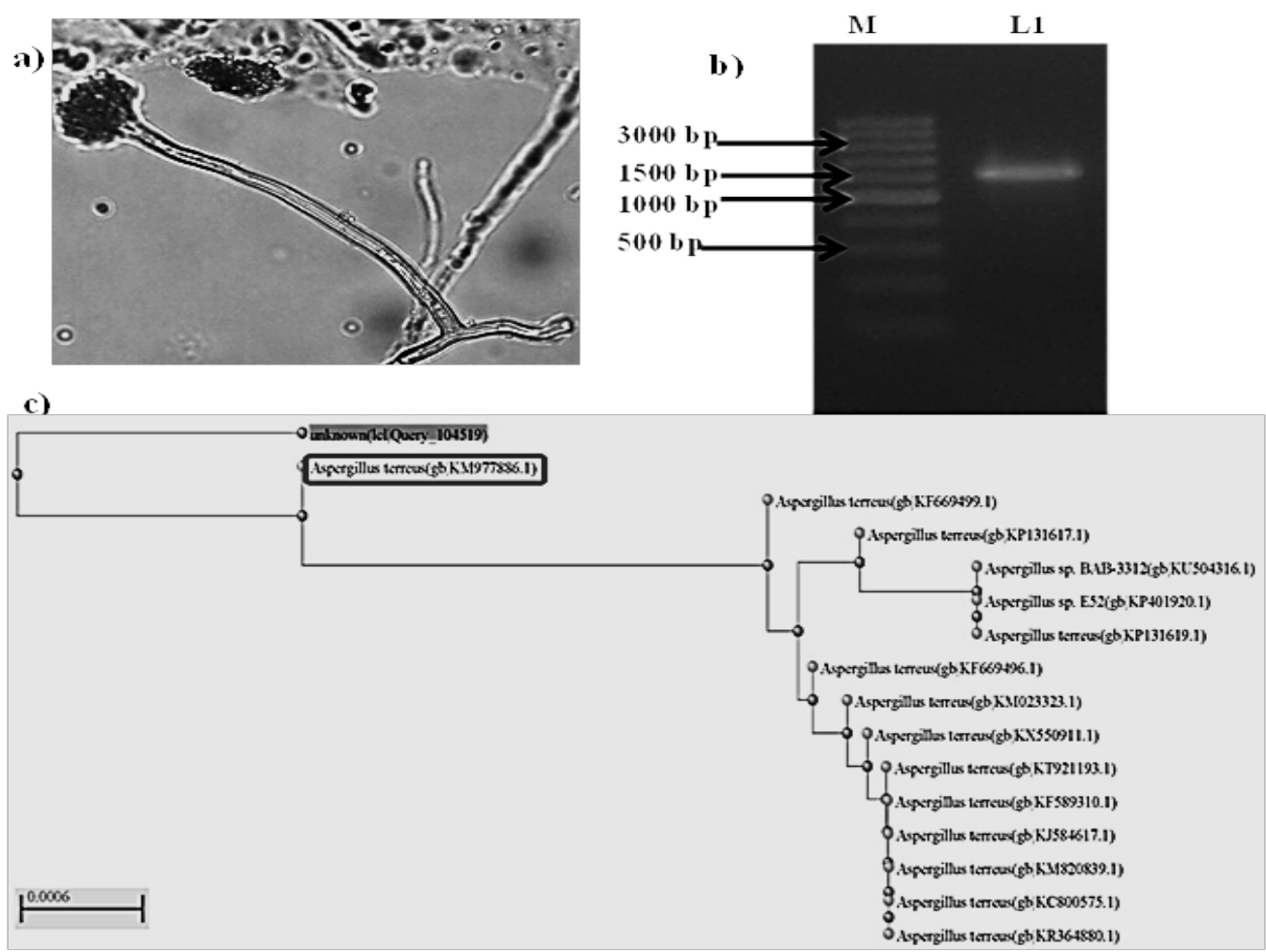

Figure 1. Identification of the most efficient heavy metal removing fungal isolate, a) Morphological identification, b) Agarose gel analysis of PCR amplification product using 18S rRNA primers for Aspergillus sp. FR1 isolate, c) Neighbor-joining tree based on $18 \mathrm{~S}$ rRNA sequences of the genus Aspergillus sp. FR1 obtained from BLAST search showing the position of isolate and related strains. $\mathrm{M}=$ Markar, $\mathrm{L} 1=$ Aspergillus sp. FR1 isolate.

In this respect, different species of Aspergillus have been reported as efficient heavy metals absorption [34]. Moreover, Dwivedi et al [35] found that many heavy metal tolerant isolates were identified as A. niger (Pb2, Cr10, Ni19, Ni27 and Ni33) and A. flavus (Pb7, Pb8, Ni35 and Ni36) by the laboratory culture. In addition, Iram et al [36] reported that among all tested fungal strains, few isolates of Aspergillus flavus and A. niger and Fusarium were tolerant to $\mathrm{Cr}$ and $\mathrm{Pb}$. The molecular identification of fungal isolate Aspergillus sp. FR1 was performed by partial $18 \mathrm{~S}$ rDNA sequencing. The apparent size of the PCR amplicon was $\sim 1500 \mathrm{bp}$, shown in Fig 1b. The analysis of 18S rRNA gene of the isolate Aspergillus sp. FR1 was sequenced with R1 primer at the forward direction and produced $1020 \mathrm{bp}$ which was compared with available $18 \mathrm{~S}$ ribosomal sequences in the NCBI database site (Gen Bank) using BLASTN. The NCBI database showed the highest percentage of similarity being $99 \%$ with Aspergillus terreus isolate YF 18S ribosomal RNA gene, partial sequence; internal transcribed spacer 1, 5.8S ribosomal RNA gene, and internal transcribed spacer 2, complete sequence; and 28S ribosomal RNA gene, partial sequence (accession number: KM977886.1). Multiple sequence alignment was developed using sequence of the isolate Aspergillus sp. FR1_Forw 1020 bp withe the sequence of the highest 15 previous homologous sequences, then a phylogenetic tree was drawn using clustal omega as shown in Fig. 1c. Neighbor joining analysis based on 18S rRNA gene sequences revealed that the isolate Aspergillus terreus strain (accession number: KM977886.1) and occupies a distinct pylogenctic position within the representative members of the genus Aspergillus, as depicted in Fig. 1c.

\subsection{Time Course of Heavy Metal Removing Aspergillus Terreus FR1 Growth}

Data illustrated by Fig. 2a show that all the tested strain grew exponentially during the first 6 days of incubation period on metal ions free Czapek Dox broth medium as a control and the same medium supplemented with different metal ions. The growth of the tested fungal strain (expressed as cell dry weight) at the end of exponential phase was found in metal ions free medium and same medium containing $\mathrm{Cu}^{+2}$ or $\mathrm{Cr}^{+5}$ ions, being $1.189 \mathrm{gL}^{-1}$ and 0.120 or $0.132 \mathrm{gL}^{-1}$, respectively . The growth parameters were calculated at 
the $\log$ phase of the growth curves and recorded in Fig. $2 \mathrm{~b}$.
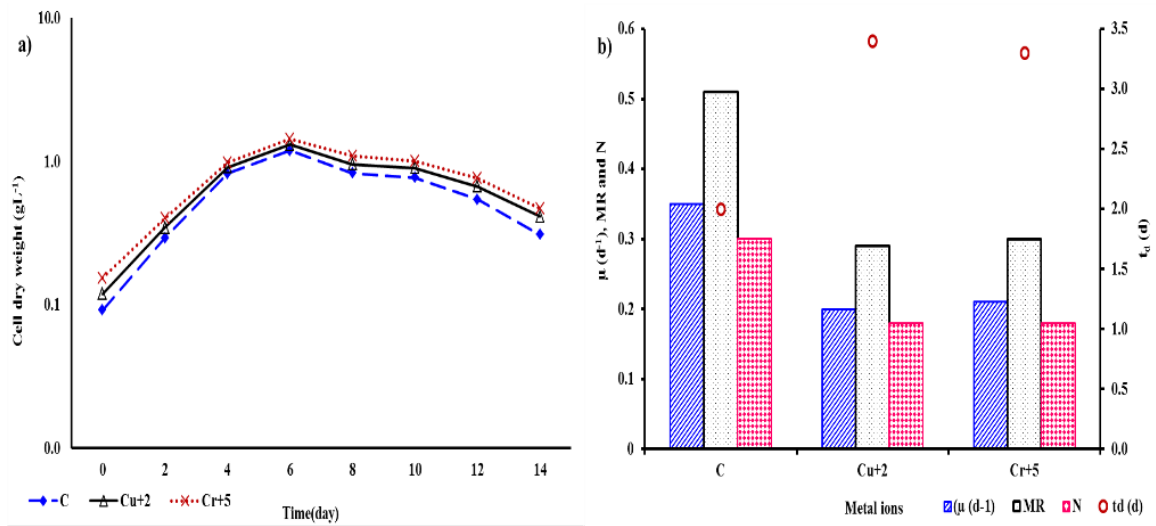

Figure 2. Growth curve a) and growth parameters b) of Aspergillus terreus FR1 on Czapek Dox broth medium containing different metal ions at concentration of $150 \mathrm{ppm}$ during 14 days of incubation period at $28^{\circ} \mathrm{C}$. C $=\mathrm{Control}$ (metal ions free medium), $\mu=$ specific growth rate, $t_{d}=$ doubling time, $M R=$ multiplication rate, $N=$ the number of generation.

Results showed that the specific growth rate $(\mu)$ was ranged from $0.35,0.20 \& 0.21 \mathrm{~h}^{-1}$, the doubling time $\left(\mathrm{t}_{\mathrm{d}}\right)$ was $2.0,3.4 \& 3.3 \mathrm{~h}$, multiplication rate $(\mathrm{MR})$ was $0.51,0.29 \& 0.30 \mathrm{~h}$ and the number of generation $(\mathrm{N})$ was $0.30,0.18 \& 0.18$ on medium free metal ions and supplemented $\mathrm{Cu}^{+2}$ and $\mathrm{Cr}^{+5}$ ions, respectively. The statistical analysis revealed that the correlation coefficient (r) between incubation time and growth in log phase on control medium and medium containing different metal ions was positively higher, where it's ranged from 0.92 to 0.99 for tested strain A. terreus FR1. The obtained results could be explained by the results found by Leung et al [37] that bioaccumulation was generally less at later growth phases due to chemical changes in the mycelium. Also, it is reported that growth A. niger and A. flavus under suitable conditions produce spherical mycelia which have been used for heavy metals accumulation.

\subsection{Optimization of Carbon and Nitrogen Sources for A. Terreus FR1 on Medium Containing Heavy Metal}

Data in Fig. 3a clearly show that lactose was the best carbon source for growth $A$. terreus FR1 in presence of $\mathrm{Cu}^{2+}$ and $\mathrm{Cr}^{5+}$ with concentration of $150 \mathrm{ppm}$ being 0.234 and $0.221 \mathrm{gL}^{-1}$ followed by glucose being 0.203 and $0.211 \mathrm{gL}^{-1}$, respectively. Whereas the minimum growth of tested strain, was noticed in medium supplemented with fructose, as compared to other tested carbon sources. Generally, it could be stated that $\mathrm{Cu}^{2+}$ and $\mathrm{Cr}^{5}$ biosorption by $A$. terreus FR1 in presence of lactose were increased about 1.8 and 1.6 fold increase as compared to sucrose as control, respectively. From the obtained results it could be concluded that the biosorption of heavy metals ions from the growing media by the selected fungi were highly correlated to the carbon source, fungal strain, content of the media and the type state free or complex and concentration of the heavy metal ion in the growing media. These results are in agreement with those of Mapolelo and Torto [38] and Yoshida et al [39] who observed that glucose was increased the heavy metal reduction rate by $S$. cerevisiae and $C$. sorokiniana. Wang and Chen [40] also described the role of glucose in biosorption depending on the type of strains and the status of metal ions (free or complex), even for the same biomass and for the same metal ions. Maygaonkar and Permeswaran [41] also stated that biosorption of $\mathrm{Na}^{+}$and $\mathrm{Mg}^{++}$by $A$. nidulans in medium supplemented with $1 \%$ sucrose was more sources at $28^{\circ} \mathrm{C}$ for 6 days. cont. $=$ Control, Different letters above the bars indicate significant differences between carbon or nitrogen sources, according to Duncan's [43] at $5 \%$ level. 

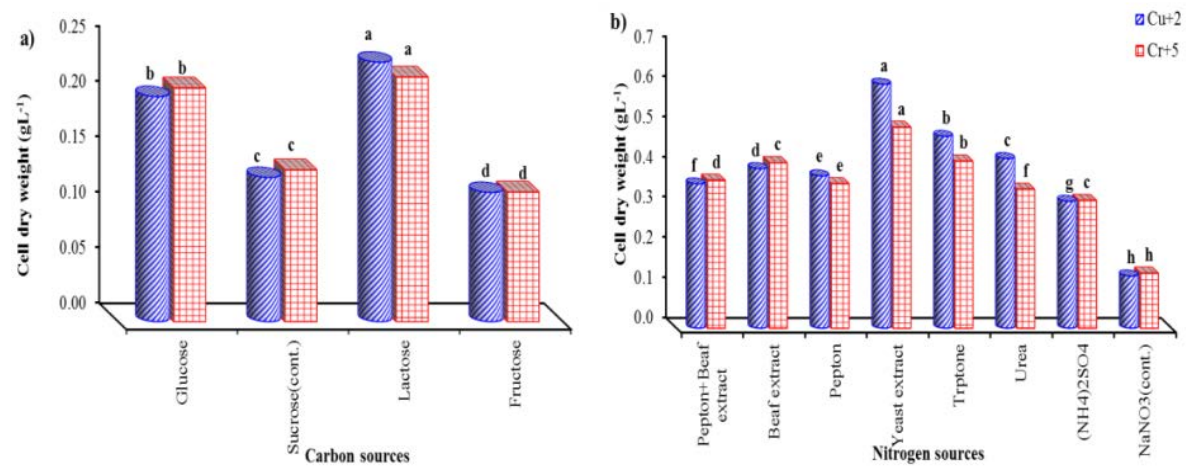

Figure 3. Biosorption of metal ions by A. terreus FR1 as influenced by different carbon a) and nitrogen b) favorable than $1 \%$ dextrose as carbon source. Whereas, Hirpara et al [42] reported that the highest reduction of chromium by $S$. rubidaea was recorded in broth medium supplemented with sucrose at $0.1 \%$ concentration.

Results in Fig. 3b clearly show that the sources of nitrogen greatly affected the growth (biosorption of heavy metal) by $A$. terreus FR1. Data showed that yeast extract was the best nitrogen source for $A$. terreus FR1 growth on modified medium supplemented with $\mathrm{Cu}^{2+}$ and $\mathrm{Cr}^{5+}$ being 0.607 and $0.500 \mathrm{gL}^{-1}$ of cell dry weight followed by tryptone being 0.477 and $0.416 \mathrm{gL}^{-1}$ of cell dry weight, respectively, followed by tryptone. These results could be interrupted on the basis organic nitrogen such as yeast extract and tryptone not only as an organic nitrogen sources but also a source of growth factors and protein which play a vital role in enhancement of the microbial growth. According to the results of Sayer et al [44], A. niger could adsorb $\mathrm{Zn}$ when growing on organic nitrogen (malt extract) with $4 \%(\mathrm{~W} / \mathrm{V}) \mathrm{Zn}_{3}\left(\mathrm{PO}_{4}\right)_{2}$. Moreover, Kumar and Riyazudin [45] added mixture of peptone and beef extract as organic nitrogen sources in medium containing different heavy metals ( $\mathrm{Co}, \mathrm{Cd} \mathrm{Ni}$ and $\mathrm{Pb}$ ) for biosorption by Bacillus spp., Pseudomonas spp., Staphylococcus spp. and A. niger. So, it could be stated that organic nitrogen sources were more favorable than inorganic sources for growth of tested fungi on medium containing metal ions at $150 \mathrm{ppm}$. Also, it could be observed that increasing the growth activity of A. terreus FR1 on modified medium contains the best nitrogen source (yeast extract) in presences of $\mathrm{Cu}^{2+}$ and $\mathrm{Cr}^{5+}$ by 4.7 and 3.7 fold as compared to control medium $\left(\mathrm{NaNO}_{3}\right)$, respectively.

\subsection{Statistical Experimental Designs for Evaluation of the Factors Affecting Heavy Metals Biosorption by A. Terreus FR1}

3.4.1 Screening of Most Significant Fermentation Parameters Using Plackett-Burman Design

Plackett-Burman screening experimental design was used to determine the influence of independent variables (lactose concentration, yeast extract concentration, $\mathrm{pH}$, temperature, inoculums size, incubation period and agitation speed) on biosorption of heavy metals by A. terreus FR1 as shown in Table 1. The design for 12 runs with two levels for each factor. Cell dry weight averages for different trials were given in $\mathrm{gL}^{-1}$. Main effect of each variable on biomass was estimated as difference between both measurements averages made at high $(+1)$ and low levels $(-1)$ of that factor. Data showed a wide variation from 0.369 to $0.879 \mathrm{~g} \mathrm{CDW} \mathrm{L}^{-1}$ and 0.199 to $0.862 \mathrm{~g} \mathrm{CDW} \mathrm{L}^{-1}$ on growth in presence of $\mathrm{Cr}^{+5}$ and $\mathrm{Cu}^{+2}$, respectively in 12 experiments due to the strong influence of variables on heavy metals biosorption. In presence $\mathrm{Cr}^{+5}$, maximal biosorption $\left(0.879 \mathrm{~g} \mathrm{CDW} \mathrm{L}^{-1}\right)$ was achieved during run number 12 with high levels of lactose concentration $(0.90 \%), \mathrm{pH}(7.0)$, incubation temperature $\left(30^{\circ} \mathrm{C}\right)$, inoculum size $(3 \%)$ and incubation periods $(7 \mathrm{~d})$, and low levels of yeast extract concentration $(0.23 \%)$ and without agitation speed (static) followed by run number 7,4 and then $3\left(0.866,0.855\right.$ and $\left.0.816 \mathrm{~g} \mathrm{CDW} \mathrm{L}^{-1}\right)$, respectively. Meanwhile, the highest biosorption of $\mathrm{Cu}^{2+}\left(0.862 \mathrm{~g} \mathrm{CDW} \mathrm{L}^{-1}\right)$ was recorded at run number 10 with high levels of incubation temperature $\left(30^{\circ} \mathrm{C}\right)$, inoculum size $(3 \%)$ and incubation periods $(7 \mathrm{~d})$ and low levels of lactose concentration $(0.85 \%)$, yeast extract concentration $(0.23 \%), \mathrm{pH}(6.0)$, without agitation speed (static) followed by run number 12 and 7 (0.771 and $\left.0.721 \mathrm{~g} \mathrm{CDW} \mathrm{L}^{-1}\right)$, respectively. The lowest removal of all tested metal ions of $\mathrm{Cr}^{+5}$ and $\mathrm{Cu}^{+2}$ were observed in run number 8 . To determine the main effect and the significance of each factor, the estimated effects, coefficients mean squares, F-values, and P-values for the 
main effect of each variable, are shown in Table 4 . The mean square (variance of effect) showed higher value for $\mathrm{Cr}^{+5}$ and $\mathrm{Cu}^{+2}$ removal in the presence of yeast extract $(0.230$ and 0.160$)$. The significance of each coefficient was determined by F- and P-values which are listed in Table 4.

The Model F-value of 382.37 and 10.82 implies the model is significant for $\mathrm{Cr}^{+5}$ and $\mathrm{Cu}^{+2}$ removal, respectively. There is only a $0.01 \%$ chance that an F-value this large could occur due to noise. Variables having a probability value (p-value) less than 0.05 were considered significant.The analyzed data in Table 4 suggests out of 7 different independent variables which were likely to play important role for improving the tested fungal growth for $\mathrm{Cr}^{+5}$ and $\mathrm{Cu}^{+2}$ removal, 3 variables (yeast extract concentration, temperature and inoculum size) and 4 variables (lactose concentration, yeast extract concentration, temperature and incubation period) significantly affected $\mathrm{Cr}^{+5}$ and $\mathrm{Cu}^{+2}$ biosorption, which had p-values ranged from 0.014 - 0.029, 0.009 - 0.035, respectively. The coefficient of determination $\left(\mathrm{R}^{2}\right)$ was 0.99 and 0.97 (which means that 99 and $97 \%$ of the total variation is explained by the model) for $\mathrm{Cr}^{+5}$ and $\mathrm{Cu}^{+2}$, respectively which indicate a satisfactory.

Table 4. Statistical analysis of variance (ANOVA) of Plackett-Burman design for heavy metal biosorption by $A$. terreus FR1.

\begin{tabular}{|c|c|c|c|c|c|c|c|c|}
\hline \multirow{3}{*}{ Variables } & \multicolumn{8}{|c|}{ Metal ions } \\
\hline & \multicolumn{4}{|c|}{$\mathrm{Cr}^{5+}$} & \multicolumn{4}{|c|}{$\mathrm{Cu}^{2+}$} \\
\hline & $\begin{array}{l}\text { Mean } \\
\text { square }\end{array}$ & df & F-Value & $\begin{array}{l}\text { p-value } \\
(\text { Prob }>F)\end{array}$ & $\begin{array}{c}\text { Mean } \\
\text { square }\end{array}$ & df & $\begin{array}{c}\text { F- } \\
\text { Value }\end{array}$ & $\begin{array}{l}\text { p-value } \\
\text { (Prob }>F)\end{array}$ \\
\hline Model & 0.040 & 11 & $\mathbf{3 8 2 . 3 7}$ & 0.040 * & 0.049 & 11 & 10.82 & $0.038 *$ \\
\hline A- Lactose & 0.006 & 1 & 52.25 & 0.088 & 0.062 & 1 & 13.54 & $0.035^{*}$ \\
\hline $\begin{array}{l}\text { B- Yeast } \\
\text { extract }\end{array}$ & 0.230 & 1 & 2163.63 & $0.014 *$ & 0.160 & 1 & 34.77 & $0.009 *$ \\
\hline C- pH & 0.006 & 1 & 54.05 & 0.086 & 0.017 & 1 & 3.81 & 0.146 \\
\hline $\begin{array}{l}\text { D- } \\
\text { Temperature }\end{array}$ & 0.081 & 1 & 769.06 & 0.023 * & 0.068 & 1 & 14.85 & $0.031 *$ \\
\hline $\begin{array}{l}\text { E- Agitation } \\
\text { speed }\end{array}$ & 0.014 & 1 & 129.53 & 0.057 & 0.002 & 1 & 0.55 & 0.513 \\
\hline $\begin{array}{l}\text { F-Inoculum } \\
\text { size }\end{array}$ & 0.052 & 1 & 490.41 & 0.029* & 0.001 & 1 & 0.13 & 0.744 \\
\hline G- & & & & & & & & \\
\hline Incubation & 0.014 & $\mathbf{1}$ & 129.53 & 0.056 & & 1 & & \\
\hline period & & & & & 0.086 & & 18.89 & $0.023^{*}$ \\
\hline H-Dummy 1 & 0.0001 & 1 & 1.00 & 0.500 & 0.000 & 1 & 0.01 & 0.942 \\
\hline J-Dummy 2 & 0.000 & 1 & 0.00 & 1.000 & 0.008 & 1 & 2.94 & 0.229 \\
\hline K-Dummy3 & 0.004 & 1 & 35.22 & 0.106 & 0.001 & 1 & 0.16 & 0.757 \\
\hline L-Dummy4 & 0.000 & 1 & 0.00 & 1.000 & 0.005 & 1 & 6.19 & 0.243 \\
\hline Std. Dev. & & & 0.01 & & & & 0.07 & \\
\hline Mean & & & 0.61 & & & & 0.55 & \\
\hline $\mathbf{R}^{2}$ & & & 0.99 & & & & 0.97 & \\
\hline
\end{tabular}

$\mathrm{df}=$ degree of freedom, ${ }^{*}$ Significant at $5 \%$ level $(\mathrm{P} \leqslant 0.05), \mathrm{Cr}^{+5}$ Sign. $=$ B- Yeast extract conc, DTemperature and F-Inoculum size, $\mathrm{Cu}^{+2}$ Sign. = A- Lactose, B- Yeast extract, D- Temperature and G-Incubation period.

Representation of the process model and a high correlation between the experimental and predicted values. By using Design Expert, the equation obtained for Plackett-Burman design (first order model) was as follows:

$$
\begin{array}{rl}
Y C r_{\text {removal }}^{+5} & 0.609+0.021(\text { lactoseconc. })-0.138(\text { yeast extractconc. })+ \\
& 0.034 \text { (agitation speed })+0.022(p H)-0.082(\text { temperature })- \\
& 0.066(\text { inoculum size })-0.034(\text { incubation period })+0.003(\text { Dummy } 1)- \\
& 0.0000003(\text { Dummy } 2)+0.0000003(\text { Dummy } 3)-0.018(\text { Dummy } 4)
\end{array}
$$




$$
\begin{aligned}
Y_{C u}^{+2} \text { removal }= & 0.551+-0.072 \text { (lactoseconc. })- \\
& 0.115(\text { yeast extractconc. })-0.014(\text { agitation speed }) \\
& -0.038(\text { pH })-0.075(\text { temperature }) 0.007(\text { inoculum size })+ \\
& 0.085(\text { incubation period })-0.002(\text { Dummy } 1)+0.020(\text { Dummy } 2)+ \\
& 0.026(\text { Dummy } 3)+0.0080(\text { Dummy } 4)
\end{aligned}
$$

The positive coefficients for all factors suggest a linear effect on the increment in activity of $\mathrm{Cr}^{+5}$ biosorption, except yeast extract concentration, temperature, inoculum size, incubation period and Dummy 4, which were negative coefficients imply a linear effect on the decrement in $\mathrm{Cr}^{+5}$ biosorption, also 1 (incubation period, Dummy 2 and Dummy 3) and 5 (lactose conc., yeast extract conc., agitation speed, $\mathrm{pH}$, temperature, Dummy 1) factors gave positive and negative impact on $\mathrm{Cu}^{+2}$ biosorption, respectively (Fig. 4).

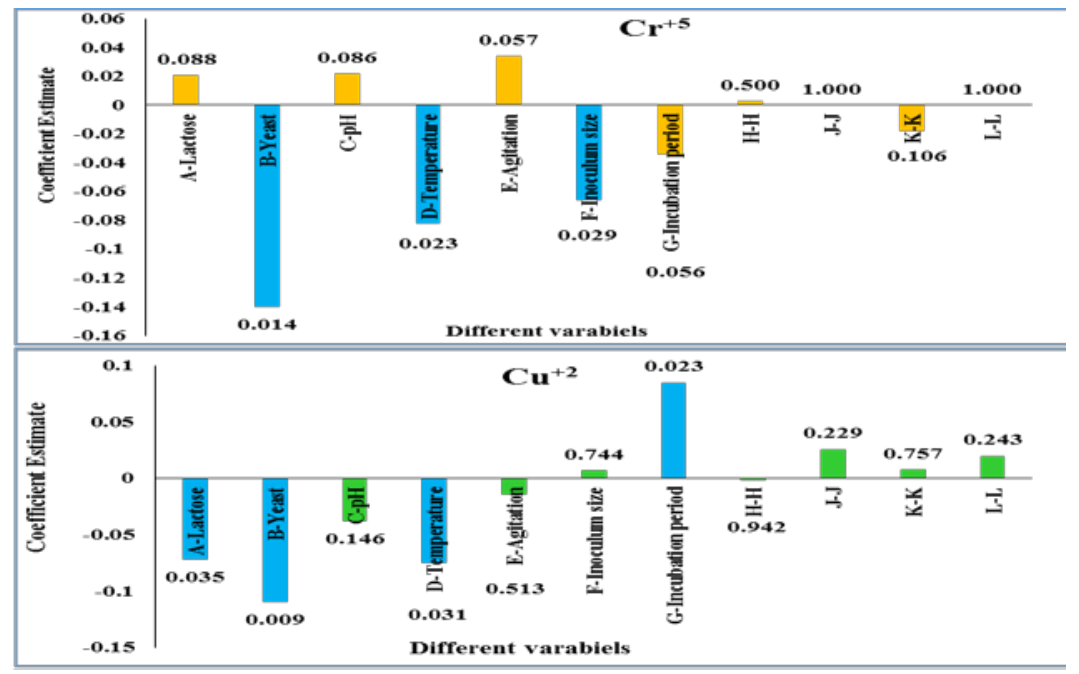

Figure 4. The extent of positive and negative effects of the eleven factors on heavy metals removal by A. terreus FR 1 and the corresponding p-values (number above each bar) of the factors showing their significance (if $\mathrm{p}<0.05$ ) based on ANOVA according to the Plackett-Burman experimental results. The blue bars indicate the positively significant factors.

The pareto graph (Fig. 5) was used to show the effect of all variables on heavy metal biosorption in Plackett-Burman experimental design. The percentage of the main effect or contribution for twelve variables was ranging from $1.00-80.57 \%$ and $1.10-22 \% \%$ for $\mathrm{Cr}^{+5}$ and $\mathrm{Cu}^{+2}$ removal, respectively. Among the twelve variables, yeast extract concentration, temperature and inoculum size showed the highest negative significant effect $\left(80.6,46.5\right.$ and $40 \%$ ), for $\mathrm{Cr}^{+5}$ biosorption, respectively. Whereas, yeast extract concentration, temperature and lactose showed the highest negative significance by $22,14.78$ and $13 \%$ and $15.15 \%$ and incubation period showed the highest positive significant (16.8\%) for $\mathrm{Cu}^{+2}$ removal, respectively. These significant factors identified by the Plackett-Burman design are considered for the next stage in the medium optimization using response surface optimization technique for the future study. The results obtained are in concordance with Fujii and Fukunag [46] and Shivakumar et al [47] revealed that the optimal $\mathrm{pH}$ for Aspergillus and Penicillium grew in medium containing $\mathrm{Cu}$ was $\mathrm{pH} 5-6$. Whereas the values of $\mathrm{pH}$ for maximum $\mathrm{Cu}^{2+}$ removal were 6- 6.5 for A. niger and A. oryzae and P. squamosus [31], 5 for T. versicolor and F. oxisporum and $\mathbf{5 . 5}$ for P. hirsutum [48]. The cell surface copper binding sites and the availability of copper in the solution are influenced by $\mathrm{pH}$. Little biosorption of $\mathrm{Cu}$ (II) ions was observed at low $\mathrm{pH}$ due to the competition between hydrogen ions and copper ions on the biosorption active sites [19]. The increase of $\mathrm{pH}$ resulted in an increased negative charge on the surface of the cell, which favored electrochemical attraction and adsorption of copper. In addition, Simonescu and Ferdes [31] observed that the optimal temperature for the $\mathrm{Cu}(\mathrm{II})$ removal by the tested fungal strains was $30^{\circ} \mathrm{C}$. 
Biosorptive removal of $\mathrm{Cr}^{+6}$ by Rhizopus arrhizus at $100 \mathrm{rpm}$ and by Rhizopus sp. [49]. Generally, it could be concluded that 3 (yeast extract concentration, temperature and inoculum size) and 4 (yeast extract and lactose concentration, temperature and incubation period) variables were selected for fungal growth on $\mathrm{Cr}^{+5}$ and $\mathrm{Cu}^{+2}$, respectively and their possible interactive effects on growth in presence of heavy metals (biosorption) were evaluated by response surface methodology.

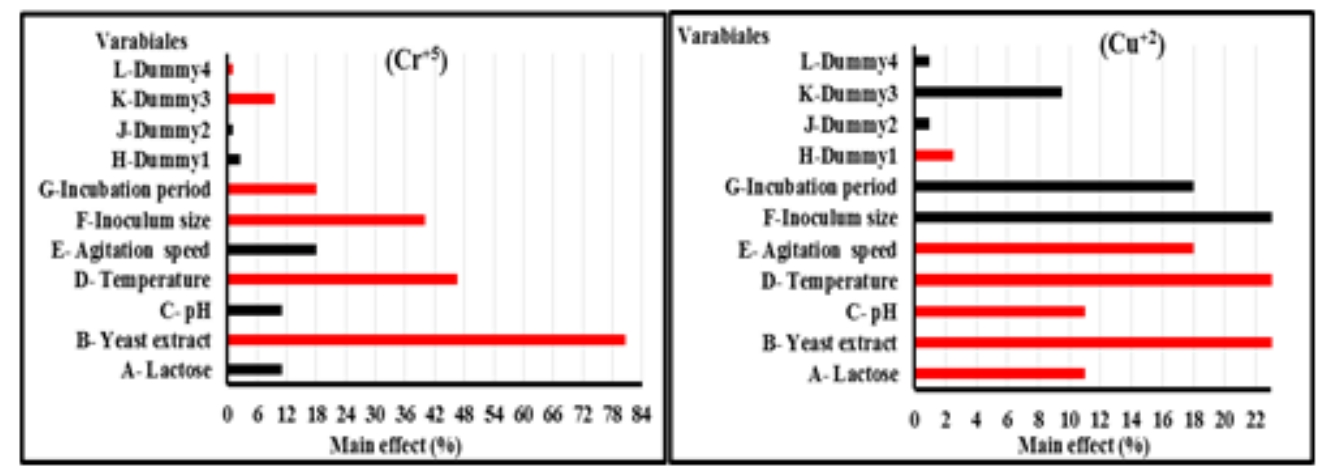

Figure 5. Pareto graph showing contribution effect \% of different variables on heavy metals removal by A. terreus FR1 based on the observation of Plackett-Burman design (the black color represents positive effects and the red color represents negative effects).

\subsubsection{Central Composite Design (CCD) and Response Surface Methodology (RSM)}

After selecting the most significant variables influencing heavy metals biosorption (grow in presence of metal ions) by A. terreus FR1 showing confidence level 97 - 99\% using Plackett-Burman design, a central composite design (CCD) was performed to determine the optimal levels and the interactions among the selected significant variables. In this study, a total of 20 and/or 30 experiments with 3 and/or 4 different combination of yeast extract concentration (A), incubation temperature $(B)$ and inoculum size $(\mathrm{C})$ and/or lactose concentration $(\mathrm{A})$, yeast extract concentration $(\mathrm{B})$, incubation temperature $(\mathrm{C})$ and incubation period (D) and were performed and the results of experiments for studying the effects of three and /or four independent variables on growth in presence of $\mathrm{Cr}^{+5}$ and $/$ or $\mathrm{Cu}^{+2}$ at three different levels coded as $-1,0$, and +1 are presented along with actual response, respectively (Table 2 and 3). The data showed great variation in growth activity. Data recorded in Table 2 showed that the highest growth activity $\left(4.31 \mathrm{gL}^{-1}\right)$ on $\mathrm{Cr}^{+5}$ was achieved at run number 6 (containing $0.15 \%$ yeast extract and inoculated with $2 \%$ inoculum size then incubated at $\left.28^{\circ} \mathrm{C}\right)$ followed by run numbers 2 and 17 . The minimum growth activity $\left(0.12 \mathrm{gL}^{-1}\right)$ was recorded in run number 1. While Data presented in Table 3 show that run numbers 9, 14, 18, 19, 26 and 30 showed a high growth activity in presence of $\mathrm{Cu}^{+2}\left(\geqslant 3.69 \mathrm{gL}^{-1}\right)$. The maximum growth $\left(3.69 \mathrm{gL}^{-1}\right)$ was achieved at run number 19 in the presence of $0.65 \%$ lactose, $0.15 \%$ yeast extract, an incubation temperature of $30{ }^{\circ} \mathrm{C}$ and 8 days incubation period, while the minimum growth $\left(1.29 \mathrm{gL}^{-1}\right)$ was observed in run number 21. The statistical significance of the model was checked by F-test and ANOVA for the response surface quadratic model are summarized in Table 5. The model F-value of 47.10 and 4.22 implied the model for $\mathrm{Cu}^{+2}$ and $\mathrm{Cr}^{+5}$ were significant, respectively. A p-value was also less than 0.0001 demonstrate the model was highly significant and indicating that there was only a $0.01 \%$ chance that a "Model F-Value" this large could occur due to noise. The determination coefficient $\mathrm{R}^{2}$ of the model was 0.96 in presence of $\mathrm{Cu}^{+2}$ and 0.79 in presence of $\mathrm{Cr}^{+5}$, indicated that $96 \%$ and $79 \%$ of the total variations were explained by the model and revealed good agreement between the experimental results and the predicted values calculated from the model. Therefore, the present $\mathrm{R}^{2}$ value hinted that the model is reliable for growth activity in presence of metal ions in the present study. Interpretation of the data was based on the signs (positive or negative effect on the response) and statistical significance of coefficients $(P<0.05)$. Interactions between two factors could appear as an antagonistic effect (negative coefficient) or a synergistic effect (positive coefficient). 
Table 5. Statistical analysis of variance (ANOVA) of C.C.D design for removal $\mathrm{Cu}^{+2}$ and $\mathrm{Cr}^{+5}$ by A. terreus FR1.

\begin{tabular}{|c|c|c|c|c|c|c|c|c|c|}
\hline \multirow[b]{2}{*}{ Variables } & \multicolumn{4}{|c|}{$\mathrm{Cu}^{+2}$} & \multirow[b]{2}{*}{ Variables } & \multicolumn{4}{|c|}{$\mathrm{Cr}^{+5}$} \\
\hline & $\begin{array}{l}\text { Mean } \\
\text { square }\end{array}$ & df & $\begin{array}{c}\text { F- } \\
\text { Value }\end{array}$ & $\begin{array}{l}\text { p-value } \\
\text { (Prob>F) }\end{array}$ & & $\begin{array}{l}\text { Mean } \\
\text { square }\end{array}$ & df & $\begin{array}{c}\text { F- } \\
\text { Value }\end{array}$ & $\begin{array}{l}\text { p-value } \\
\text { (Prob>F) }\end{array}$ \\
\hline Model & 0.55 & 10 & 47.1 & $<0.0001 *$ & Model & 2.62 & 9 & 4.2 & $0.017^{*}$ \\
\hline $\begin{array}{l}\text { A- Lactose } \\
\text { conc. }\end{array}$ & 0.01 & $\mathbf{1}$ & 1.2 & 0.296 & $\begin{array}{l}\text { A- Yeast extract } \\
\text { conc. }\end{array}$ & 1.62 & 1 & 2.6 & 0.137 \\
\hline $\begin{array}{l}\text { B- Yeast extract } \\
\text { conc. }\end{array}$ & 0.32 & 1 & 27.4 & $<0.0001 *$ & $\begin{array}{l}\text { B- Incubation } \\
\text { temperature }\end{array}$ & 0.19 & 1 & 0.3 & 0.591 \\
\hline $\begin{array}{l}\text { C-Incubation } \\
\text { temperature }\end{array}$ & 0.06 & 1 & 5.1 & $0.036 *$ & C-Inoculum size & 0.13 & 1 & 0.2 & 0.657 \\
\hline $\begin{array}{l}\text { D-Incubation } \\
\text { period }\end{array}$ & $\mathbf{0 . 0 3}$ & $\mathbf{1}$ & 2.5 & 0.130 & $A B$ & 3.09 & 1 & 5.0 & $0.050 *$ \\
\hline AB & 0.21 & 1 & 18.1 & $0.000^{*}$ & AC & 9.52 & 1 & 15.3 & $0.003 *$ \\
\hline AC & 0.19 & 1 & 16.0 & $0.001 *$ & BC & 2.14 & 1 & 3.5 & 0.093 \\
\hline AD & 0.25 & 1 & 21.1 & $0.000 \%$ & $A^{\wedge 2}$ & 0.61 & 1 & 1.0 & 0.345 \\
\hline BC & 2.39 & 1 & 203.4 & $<0.0001 *$ & $B^{\wedge 2}$ & 6.76 & 1 & 10.9 & $0.008^{*}$ \\
\hline BD & 0.01 & 1 & 1.0 & 0.343 & $\mathrm{C}^{\wedge 2}$ & 1.24 & 1 & 2.0 & 0.189 \\
\hline CD & 0.13 & 1 & 11.5 & $0.003^{*}$ & & & & & \\
\hline Residual & & & 0.22 & & & 4.8 & & & \\
\hline Std. Dev. & & & 0.11 & & & & & & \\
\hline Mean & & & 2.99 & & & & & 2. & \\
\hline $\mathbf{R}^{2}$ & & & 0.96 & & & & & 0.7 & \\
\hline
\end{tabular}

$\mathrm{df}=$ degree of freedom, ${ }^{*}$ Significant at $5 \%$ level $(\mathrm{P} \leqslant 0.05), \mathrm{Cu}^{+2}$ Sign. $=\mathrm{B}-$ Yeast extract conc., CTemperature, $\mathrm{AB}, \mathrm{AC}, \mathrm{AD}, \mathrm{BC}$ and $\mathrm{CD}, \mathrm{Cr}^{+5}$ Sign. $=\mathrm{AB}, \mathrm{AC}$ and $\mathrm{B}^{-2}$.

From the degree of significance, in presence of $\mathrm{Cu}^{+2}$, the coefficients of model term, 2 variables yeast extract concentration (B) and incubation temperature $(\mathrm{C})$ and interaction between two variables $(\mathrm{AB}, \mathrm{AC}$, $\mathrm{AD}, \mathrm{BC}$ and $\mathrm{CD}$ ) are significant influences on growth activity. The highest probability values were recorded in $\mathrm{C}$ variable (incubation temperature) and interaction between $\mathrm{C}$ (incubation temperature) and $\mathrm{D}$ (incubation period) being 0.003 and 0.036 , respectively. The mathematical model describing the relationship between variables (A, B, C and D) and response (Y) for growth activity in medium supplemented with $\mathrm{Cu}^{+2}$ could be obtained by the following second order polynomial equation:

$$
\begin{aligned}
Y_{C u^{+2}=} & -14.6+5.5(\text { Lactoseconc. })+129.2(\text { Yeastextractconc. })+ \\
& 0.8(\text { Temperature })-1.5(\text { Incubationperiod })-14.5\left(\text { Lactoseconc. }{ }^{Y} \text { eastextractconc. }\right) \\
& -0.3\left(\text { Lactoseconc. }{ }^{T} \text { emperature }\right)+0.6\left(\text { Lactoseconc. }{ }^{I} \text { ncubationperiod }\right)- \\
& 4.9\left(\text { Yeastextractconc. }{ }^{T} \text { emperature }\right)+0.7\left(\text { Yeastextractconc. }{ }^{I} \text { ncubationperiod }\right) \\
+ & 0.04\left(\text { Temperature }{ }^{I} \text { ncubationperiod }\right)
\end{aligned}
$$

With respect to $\mathrm{Cr}^{+5}$ removal by tested fungi, the coefficients of model term, interaction between two variables $(\mathrm{AB}$ and $\mathrm{AC})$ and quadratic of one variables $\left(\mathrm{B}^{\wedge} 2\right)$ are significant influences on growth activity. The highest probability values were recorded in interaction between A (yeast extract concentration) and $\mathrm{B}$ (incubation temperature) being 0.05 . The mathematical model describing the relationship between variables $\left(\mathrm{A}, \mathrm{B}\right.$ and $\mathrm{C}$ ) and response $(\mathrm{Y})$ for growth activity in medium supplemented with $\mathrm{Cr}^{+5}$ could be obtained by the following second order polynomial equation:

$$
\begin{aligned}
Y C r^{+5} & =-190.1-76.5(\text { Yeastextractconc. })+15.4(\text { Temperature }) \\
& -10.3(\text { Inoculumsize })-3.6\left(\text { Yeastextractconc. }{ }^{T} \text { emperature }\right) \\
& +21.0\left(\text { Yeastextractconc. }{ }^{I} \text { noculumsize }\right)+0.1\left(\text { Temperature }^{I} \text { noculumsize }\right) \\
& +311.8\left(\text { Yeastextractconc. }^{2}\right)-0.3\left(\text { Temperature }^{2}\right)+0.9\left(\text { Inoculumsize }^{2}\right)
\end{aligned}
$$


Based on the model equation, three-dimensional response surface and two-dimensional contour plots graphically explain the interaction among variables and determine the optimum level of each factor for growth activity (Figs. 6 - 7). Data presented in Fig. 6, a-f revealed that growth activity was highly and interactively influenced by all selected variables. Cell dry weight predicted to be increased with high increase in concentrations of lactose $(0.85 \%)$ and low in yeast extract concentration at $0.15 \%$ when incubation temperature is maintained in the selected medium level at $28^{\circ} \mathrm{C}$ and incubation period (Fig. $6 \mathrm{a}$ ). Any further increases in these concentrations led to a decrease in cell dry weight. Optimum biomass yield could be possible with high lactose concentration $(0.85 \%)$ and in presence of incubation temperature $28^{\circ} \mathrm{C}$, yeast extract concentration at $0.15 \%$ and incubation period 8 days (Fig. 6b). A similar response curve in Fig. 6c showed the interaction of lactose concentration (A) and incubation period (D) by yeast extract concentration (B) at low value; the maximum cell dry weight was attained beyond both high levels of lactose concentration and medium level of incubation period and incubation temperature. Cell dry weight predicted to be increased with high increase in concentrations of yeast extract concentration $(0.15 \%)$ and medium in temperature for $28^{\circ} \mathrm{C}$ when incubation period is maintained in the selected low level at 32h (Fig. $6 \mathrm{~d})$. Fig. 6e illustrated the interaction of low incubation period and low yeast extract concentration by lactose concentration (A) at high value. The maximum cell dry weight was attained beyond medium level of incubation temperature and incubation period when lactose concentration is maintained in the selected higher level at (0.85\%) (Fig. 6f). Data presented in Fig. 7, a-c revealed that growth activity was highly and interactively influenced by all selected cell dry weight predicted to be increased with low in concentrations of yeast extract $(0.15 \%)$ and moderate increase in incubation temperature $\left(28^{\circ} \mathrm{C}\right)$ when inoculum size is maintained in the selected moderate level at 2\% (Fig. 7a). Any further increases in these concentrations led to a decrease in biomass. Optimum biomass yield could be possible with moderate inoculum size and in presence low concentration of yeast extract in medium concentration (Fig. 7b). A similar response curve in Fig. 7c showed the interaction of moderate inoculum size and temperature by low yeast extract concentration. From the previous results it could be concluded that optimized conditions (modified basal medium) were more favorable than un -optimized conditions (basal medium) for heavy metals biosorption (28 and 30 fold increase over control in presence of $\mathrm{Cu}^{+2}$ and $\mathrm{Cr}^{+5}$, respectively). The cell dry weight was increased after using central composite design (CCD) and response surface methodology (RSM) for tested fungi in presence of $\mathrm{Cu}^{+2}$ and $\mathrm{Cr}^{+5}$ about 4.3 and 4.6 fold, as compared with Plackett-Burman design, respectively.

Obtained results are in accordance with those obtained by Kumar et al [50] they reported that the best incubation temperature for reduction of heavy metals ( $\mathrm{Zn}$ and $\mathrm{Cd}$ ) by A. niger was $30^{\circ} \mathrm{C}$. Also, Shivakumar et al [47] who revealed that the highest removal heavy metals by $A$. niger $(\mathrm{Ni}, \mathrm{Cr}, \mathrm{Cu}, \mathrm{Zn}$ and $\mathrm{Pb})$ and $A$. flavus $\left(\mathrm{Ni}, \mathrm{Cu}, \mathrm{Zn}\right.$ and $\mathrm{Pb}$ ) was achieved at temperature ranging from $25-30^{\circ} \mathrm{C}$. The decreased metal accumulation was noticed at low temperature between $10-20^{\circ} \mathrm{C}$ and high temperature between $35-40^{\circ} \mathrm{C}$. Moreover Jha et al [51] revealed that the yeast extract was a vital component to simulate the rate of $\mathrm{Cu}^{+2}$ uptake by $A$. lentulus which enhanced about $18 \%$ of biosorption while increased about $21 \%$ of biosorption rate in presence mixture of glucose+ yeast extract. In Plackett-Burman design, the amount of metal ions $\left(\mathrm{Cr}^{+5}\right.$ and $\left.\mathrm{Cu}^{+2}\right)$ adsorbed per unit biomass (specific metal ions uptake) was 22.73 and $38.95 \mathrm{ppmg}^{-1}$ with 86.67 and $77.67 \%$ of efficiency at initial concentration of $150 \mathrm{ppm}$, respectively. While in respect of central composite design (CCD), the amount of metallic ion biosorbed per gram of biomass with efficiency $\%$ was 1.94 to $6.21 \mathrm{ppmg}^{-1}$ with 84.73 to $94.43 \%$ of efficiency, respectively (Data not shown). From previous results it could be summarized that the use of central composite design (CCD) led to increase the efficiency of heavy metals removed from media supplemented with metal ions by A. terreus FR1 (9.0 and 9.1\% over increase of $\mathrm{Cr}^{+5}$ and $\mathrm{Cu}^{+2}$, respectively) as compared to Plackett-Burman design. Similar results were obtained by Marandi et al [52] who found the highest heavy metal uptake efficiency by P. chrysosporium was $57 \%$ for $\mathrm{Zn}^{+2}$ and $87 \%$ for $\mathrm{Pb}^{+2}$ at $100 \mathrm{ppm}$ of concentration. Moreover, Simonescu and Ferdeş [31] recorded the maximum $\mathrm{Cu}^{+2}$ removal capacity by A. oryzae ATCC20423 was ranged between 69 and $88 \%$. In addition, Ekmekyapar et al [53] observed that the increase in biomass concentration led to the decrease in the metal specific uptake. 

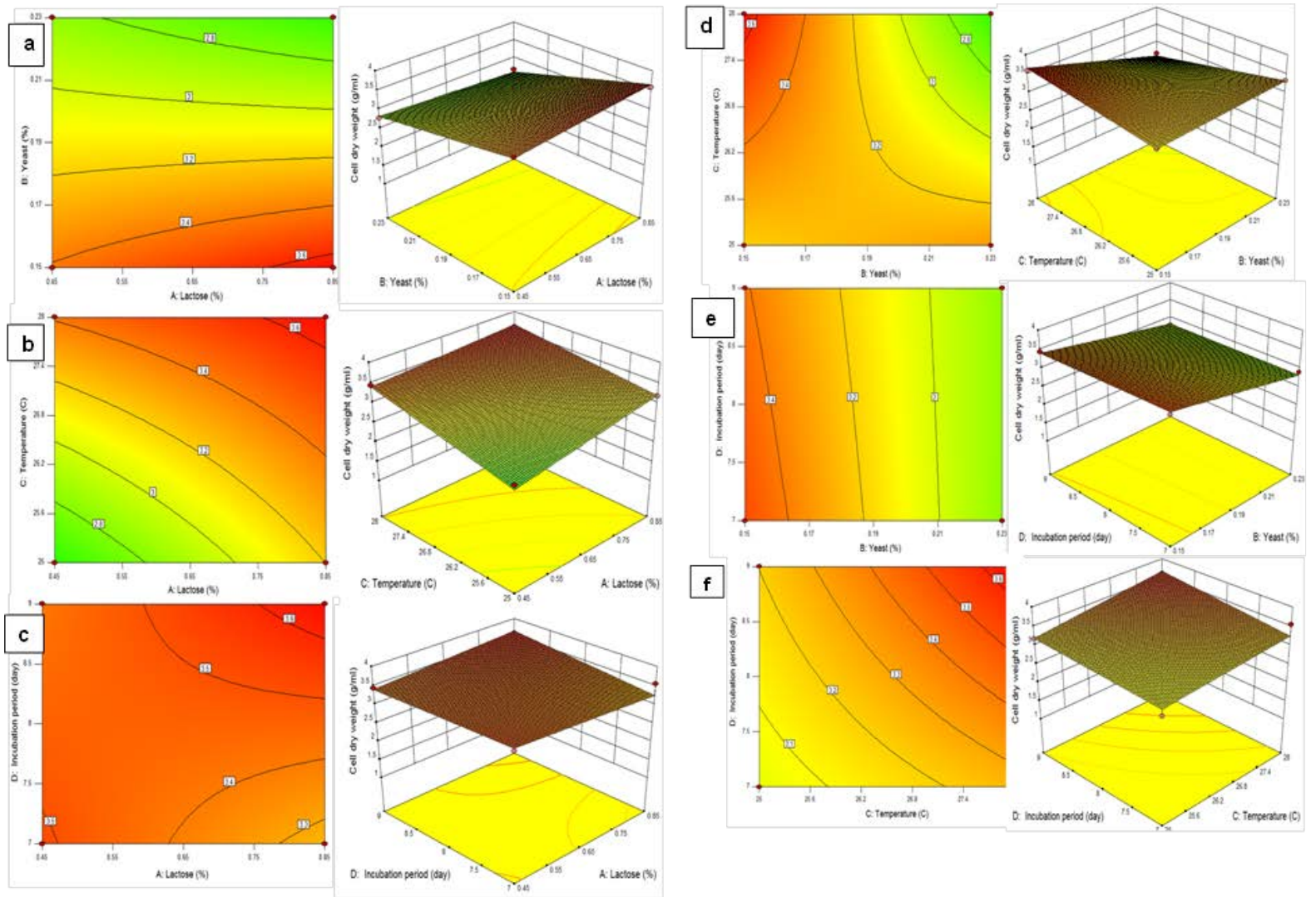

Figure 6. Three-dimensional response surface and two-dimensional contour plots showing the effect of lactose concentration, yeast extract concentration, incubation temperature and incubation period and their mutual effect on the growth of $A$. terreus $\mathrm{FR} 1$ in presence of $\mathrm{Cu}^{+2}$. a) Lactose concentration vs Yeast extract concentration with incubation temperature at $28^{\circ} \mathrm{C}$ for 8 day Incubation period. b) Lactose concentration vs Incubation temperature with yeast extract concentration at $0.15 \%$ for 8 day incubation period. c) Lactose concentration vs Incubation period with yeast extract concentration at $0.15 \%$ for temperature at $28^{\circ} \mathrm{C}$. d) Yeast extract concentration vs Incubation temperature with lactose concentration at0.85\% for 8 day incubation period. e) Yeast extract concentration vs Incubation period with lactose concentration at $0.85 \%$ for temperature at $28^{\circ} \mathrm{C}$. f) Incubation temperature vs Incubation period with lactose concentration at $0.85 \%$ for yeast extract concentration at $0.15 \%$.

\subsection{Some Application of Heavy Metals Removing Resistant Strain}

Some applications of reduction of heavy metals from Egyptian phosphatic fertilizer sample (Tri-phosphate) which contains $\mathrm{Co}, \mathrm{Cu}, \mathrm{Pb}, \mathrm{Cr}, \mathrm{Cd}$ and $\mathrm{Zn}$ using living and dead A. terreus FR1 cells were tabulated in Table 6 . The biosorption of heavy metals efficiency from tri-phosphate fertilizer by living A. terreus FR1 cells showed maximum removal of $\mathrm{Zn}(100 \%)$ followed by $\mathrm{Cu}(98.7 \%)>\mathrm{Cd}(98.4 \%)>\mathrm{Co}(97.0 \%)>\mathrm{Pb}$ $(95.3 \%)>\operatorname{Cr}(90.5 \%)$, respectively. While, the adsorption efficiency of heavy metals from tri-phosphate fertilizer sample by dead fungal cells were in order of $\mathrm{Zn}(100.0 \%)>\mathrm{Cu}(98.7 \%)>\mathrm{Cd}(98.5 \%)>\mathrm{Co}$ $(96.9 \%)>\mathrm{Pb}(95.3 \%)>\mathrm{Cr}(63.1 \%)$. Similar investigations were carried out and the present results were obtained after 6 days as incubation period may be, if the incubation period is longer then that trend of results could be changed. Same trend of results has been stated by Zaied et al [54] found that Micrococcus sp. has the ability to adsorb $79.22 \%$ of Pb. Moreover, the dead bacterial cells of Bacillus sp. showed $44.73 \%$ adsorption of $\mathrm{Cu}$ and Pseudomonas sp. adsorbed $86.66 \%$ of $\mathrm{Cd}$ [55]. In addition, Karakagh et al [56] revealed the inactivated bacterial cells increased with increasing initial concentrations of these metals from $50 \mathrm{mg} \mathrm{L}^{-1}$ to $400 \mathrm{ppm}$, Cd biosorption increased from 4.11 to $32.63 \mathrm{mg} \mathrm{g}^{-1}$ for Actinomyces sp., 3.39 to 33.18 $\mathrm{mg} \mathrm{g}^{-1}$ for Streptomyces sp. and 3.96 to $38.71 \mathrm{mg} \mathrm{g}^{-1}$ for Bacillus sp., respectively and Ni biosorption increased from 7.1 to $36.55 \mathrm{mg} \mathrm{g}^{-1}$ for Actinomyces sp., 5.47 to $34.82 \mathrm{mg} \mathrm{g}^{-1}$ for Streptomyces sp. and 4.08 to $32.8 \mathrm{mg} \mathrm{g}^{-1}$ for Bacillus sp. From the previous results, it could be noticed that no significant differences 
between reduction of heavy metals in tri-phosphate fertilizer sample using adsorption (dead cells) and absorption (living cells) mechanisms by strain A. terreus FR1. Among of heavy metals were presented in phosphate fertilizer sample, $\mathrm{Zn}$ and $\mathrm{Cu}$ reached the highest reduction percentage by tested strain.
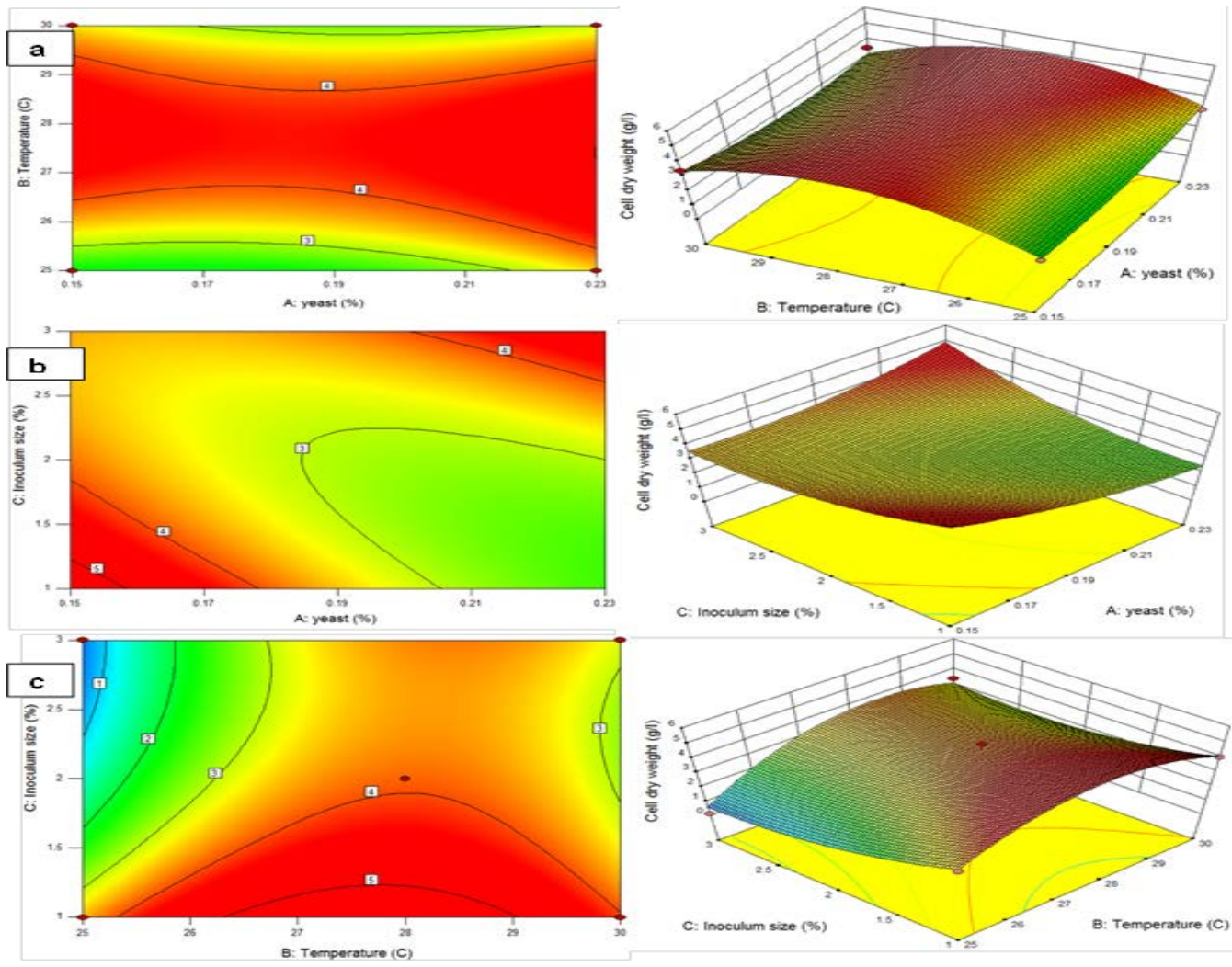

Figure 7. Three-dimensional response surface and two-dimensional contour plots showing the effect of yeast extract concentration, incubation temperature and inoculum size and their mutual effect on the growth of A. terreus FR1 in presence of $\mathrm{Cr}^{+5}$. a) Yeast extract concentration vs incubation temperature with inoculum size at 2\%.b) Yeast extract concentration vs inoculum size with incubation temperature at $28^{\circ} \mathrm{C} . \mathrm{c}$ ) Incubation temperature vs inoculum size with yeast extract concentration at $0.15 \%$.

Table 6. Absorption and adsorption of heavy metals from tri-phosphate fertilizer sample using living and dead cells of A. terreus FR1 after 6 days incubation period.

\begin{tabular}{|c|c|c|c|c|c|c|c|}
\hline \multirow{2}{*}{$\begin{array}{l}\text { Heavy } \\
\text { metal }\end{array}$} & \multirow{2}{*}{$\begin{array}{l}\text { Initial } \\
\text { conc. } \\
(\mathrm{ppm})\end{array}$} & \multicolumn{3}{|c|}{$\begin{array}{c}\text { Living cells of } A . \text { terreus } \\
\text { FR1 }\end{array}$} & \multicolumn{3}{|c|}{ Dead cells of $A$. terreus FR1 } \\
\hline & & $\begin{array}{c}\text { Res. } \\
(\mathrm{ppm})\end{array}$ & $\begin{array}{l}\text { Rem. } \\
\text { (ppm) }\end{array}$ & $\begin{array}{c}\mathrm{E} \\
(\%) \\
\end{array}$ & $\begin{array}{l}\text { Res. } \\
(\mathrm{ppm})\end{array}$ & $\begin{array}{l}\text { Rem. } \\
\text { (ppm) }\end{array}$ & $\begin{array}{c}\mathrm{E} \\
(\%) \\
\end{array}$ \\
\hline $\mathrm{Co}$ & 10 & 0.30 & $9.7^{\mathrm{d}}$ & $97.0^{c}$ & 0.31 & $9.69^{d}$ & $96.9^{\mathrm{c}}$ \\
\hline $\mathrm{Cu}$ & 13 & 0.17 & $12.83^{\mathrm{c}}$ & $98.7^{\mathrm{bc}}$ & 0.168 & $12.83^{\mathrm{c}}$ & $98.7^{\mathrm{bc}}$ \\
\hline $\mathrm{Pb}$ & 3 & 0.14 & $2.86^{\mathrm{e}}$ & $95.3^{\mathrm{d}}$ & 0.142 & $2.86^{\mathrm{e}}$ & $95.3^{\mathrm{d}}$ \\
\hline $\mathrm{Cr}$ & 95 & 9.01 & $85.99^{\mathrm{b}}$ & $90.5^{\mathrm{e}}$ & 35.05 & $59.95^{\mathrm{b}}$ & $63.1^{\mathrm{e}}$ \\
\hline $\mathrm{Cd}$ & 9 & 0.14 & $8.86^{\mathrm{d}}$ & $98.4^{\mathrm{bc}}$ & 0.137 & $8.86^{\mathrm{d}}$ & $98.5^{\mathrm{bc}}$ \\
\hline $\mathrm{Zn}$ & 131 & 0.06 & $130.94^{\mathrm{a}}$ & $100.0^{\mathrm{a}}$ & 0.04 & $130.96^{\mathrm{a}}$ & $100.0^{\mathrm{a}}$ \\
\hline
\end{tabular}

conc. $=$ concentration, Res. $=$ Residual heavy metal $(\mathrm{ppm})$, Rem.= Removal heavy metal $(\mathrm{ppm}), \mathrm{E}=$ uptake efficiency, Removal heavy metals= initial heavy metal - residual heavy metal. Values in the same column followed by the same letter are not significantly different from each other, according to Duncan's [43] at 5\%level. 


\section{Conclusions}

From the present investigation, it could be summarized that strain A. terreus FR1 which is isolated from Egyptian phosphate fertilizer increases the efficiency in heavy metals $\left(\mathrm{Cu}^{+2}\right.$ and $\left.\mathrm{Cr}^{+5}\right)$ reduction after optimizing the nutritional and environmental factors using response surface methodology (RSM), which

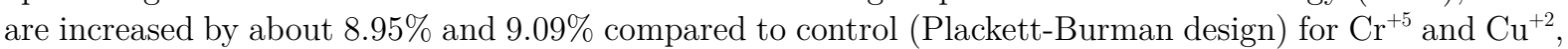
respectively. Some application of reduction of heavy metals from Egyptian phosphatic fertilizer sample (Tri-phosphate) uses living and dead fungal cells as absorption and adsorption mechanism, respectively. There is no difference signification between absorption and adsorption mechanisms for reduction of heavy metals from sample using strain of $A$. terreus FR1.

\section{References}

1. G. Sarrett, L. Avoscan, M. Carrière, R. Collins, N. Geoffroy, J. Carrot, F. Covès, and B. Gouget, "Chemical forms of selenium in the metal-resistant bacterium Ralstonia metallidurans CH34 exposed to selinite and selenite,". Applied and Environmental Microbiology, vol.71, pp. 2331-2337, 2005.

2. P.C.Patel, F. Goulhen, C. Boothman, A.G. Gault, J.M. Charnock, K. Kalia, and J.R Lloyd, "Arsenate detoxification in a Pseudomanoad hypertolerant to arsenic," Archives of Microbiology, vol.187, pp.171-183, 2007.

3. A.I. Zoubolis, M.X. Loukidou, and K.A. Matis, "Biosorption of toxic metals from aqueous solution by bacteria strains isolated from metal polluted soils," Process Biochemistry, vol. 39, pp. 909-916, 2004.

4. M. K. Zhang, Z. Y. Liu, and H. Wang, "Use of single extraction methods to predict bioavailability of heavy metals in polluted soils to rice," Communications in Soil Science and Plant Analysis, vol. 41, no. 7, pp.820-831, 2010.

5. P.K. Rai, "Heavy metal phytoremediation from aquatic ecosystems with special reference to macrophytes," Critical Reviews in Environmental Science and Technology, vol. 39, no. 9, pp.697-753, 2009.

6. I. Suciu, C. Cosma, M. Todica, S.D. Bolboaca, and L. Jantschi, "Analysis of soil heavy metal pollution and pattern in central Transylvania," International Journal of Molecular Sciences, vol. 9, pp. 434-453, 2008.

7. A.E. Mohamed, M.N. Rashed, and A. Mofty, "Assessment of essential and toxic elements in some kinds of vegetables," Ecotoxicology and Environmental Safety, vol. 55, pp. 251-260, 2003.

8. D.J. Oyedele, C. Asonugho, and O.O. Awotoye, "Heavy metals in soil and accumulation by edible vegetables after phosphate fertilizer application," Electronic Journal of Environmental Agricultural Food Chemistry, vol. 5, no. 4, pp.1446-1453, 2006.

9. A. Qishlaqi, F. Moore, and G. Forghani, "Impact of untreated wastewater irrigation on soils and crops in Shiraz sub urban area, SW Iran," Environmental Monitoring and Assessment, vol. 141, pp. 257-273, 2008.

10.N. Ahalya, T.V. Ramachandra, and R.D. Kanamadi, "Biosorption of heavy metals," Research Journal of Chemistry and Environment, vol. 7, pp. 71-78, 2003.

11.E. Fosso-Kankeu, and A. F. Mulaba-Bafubiandi, "Implication of plants and microbial metalloproteins in the bioremediation of polluted waters: a review," Physics and Chemistry of Earth, vol. 67-69, pp. 242-252, 2014.

12.G.M. Gadd, and C. White, "Microbial treatment of metal pollution: a working biotechnology?," Tibtech, vol.11, pp.353-359, 1993.

13.F. Veglio, and F. Beolchini, "Removal of metals by biosorption: a review Chemical" Hydrometallurgy, vol. 44, pp. 301-316,1997.

14.S.S Ahluwalia,and D. Goyal, "Microbial and plant derived biomass for removal of heavy metals from wastewater," Bioresource Technology, vol. 98, pp.2243-2257, 2007.

15.M.N. Zafar, R. Nadeem, and M.A. Hanif, "Biosorption of nickel from protonated rice bran," Journal of Hazardous Materials, vol. 143, pp. 478-485, 2007.

16.B. Hemambika, M. J. Rani, and V. R. Kannan, "Biosorption of heavy metals by immobilized and dead fungal cells: A comparative assessment," Journal of Ecology and the Natural Environment, vol. 3, no.1, pp.1-10, 2011.

17.B. Hemambika, M. J. Rani, and V. R. Kannan, "Biosorption of heavy metals by immobilized and dead fungal cells: A comparative assessment," Journal of Ecology and the Natural Environment, vol. 3, no.1, pp.1-10, 2011.

18.G. Yan, and T. Viraraghavan, "Heavy metal removal from aqueous solution by fungus Mucor rouxii," Water Research, vol. 37, pp. 4486-4496, 2003.

19.akht, H. Zilouei, and K. Karimi, "Biosorption by different morphologies of fungus Mucor indicus," International Biodeterioration and Biodegradation, vol. 65, p. 294, 2011. 
20.A. H. Abd El Hameed, W. E. Eweda, Kh. A.A. Abou-Taleb, and H.I. Mira, "Biosorption of uranium and heavy metals using some local fungi isolated from phosphatic fertilizers," Annals of Agricultural Science, vol. 60, no.2, pp.355-351, 2015.

21.Difco Manual, "Dehydrated culture media and reagents for microbiology,". Laboratories incorporated Detroit, Michigan, 48232 USS, p.621, 1984.

22.T.J. White, T. Bruns, S. Lee, and J. Taylor, "Amplification and direct sequencing of fungal ribosomal RNA genes for phylogenetics," in PCR Protocols: A Guide to Methods and Applications. M. A.Innis, D.H. Gelfand, J.J. Sninsky, and T.J. White, (eds.). San Diego, CA: Academic Press, pp. 315-322, 1990.

23.P. Nimnoi, N. Pongsilp, and S. Lumyong, "Endophytic actinomycetes isolated from Aquilaria crassna Pierre ex Lec and screening of plant growth promoter's production." World Journal of Microbiology and Biotechnology, vol. 26, pp. 193-203, 2010.

24.NCBI, "National Center for Biotechnology Information," Available: http://www.ncbi.nlm.nih.gov/BLAST/, 2014.

25.R.L. Plackett, and J.P. Burman, "The design of optimum multifactorial experiments," Biometrika, vol.33, pp. 305-325, 1946.

26.S. Iram, and S. Abrar, "Biosorption of copper and lead by heavy metal resistant fungal isolates," International Journal of Scientific and Research Publications, vol. 5, no. 1, pp. 196- 265, 2015.

27.A.G. Marr, E. H. Nilson, and D.J. Clark, "The maintenance requirement of Escherichia coli," Annals of the New York Academy of Sciences, vol. 102, pp. 536-548, 1963.

28.R. Y. Stanier, M. Doudoroff, and E. A. Adelberg, "General Microbiology "3rd (Ed). Macmillan and co. Ltd. London, pp.302-306, 1970.

29.H.W. Doelle, "2 - Enzymes, coenzymes and bacterial growth kinetics,". in Bacterial Metabolism, Ed 2nd. Academic Press, pp: 38-83, 1975.

30.A. Javaid, R. Bajwa, and A. Javaid, "Biosorption of heavy metals using a dead macro fungus schizophyllum commune fries: evaluation of equilibrium and kinetic models," Pakistan Journal of Botany, vol. 42, no. 3, pp. 2105-2118, 2010.

31.C.M. Simonescu, and M. Ferdes, "Fungal biomass for $\mathrm{Cu}$ (II) uptake from aqueous systems," Polish Journal of Environmental Studies, vol. 21, no. 6, pp.1831-1839, 2012.

32.IBM®SPSS® "StatisticsVersion 19.0, SPSS Inc.," Chicago, Illinois, 2011.

33.H.L. Barnett, and B. B. Hunter, "The illustrated genera of imperfect fungi," 4th (Edn.). Aps Press, Saint Paul, Minnesota, pp.1-218, 1998

34.S. Congeevaram, S. Dhanarani, J. Park, M. Dexilin, and K. Thamaraiselvi, "Biosorption of chromium and nickel by heavy metal resistant fungal and bacterial isolates," Journal of Hazardous Materials, vol. 146, pp. 270-277, 2006.

35.S. N. Dwivedi, R. P. Mishra, and S. Alava, "Phytochemistry pharmacological studies and traditional benefits of Trachyspermum ammi (Linn.) Sprague,” International Journal of Pharmacy \& Life Sciences, vol. 5, pp.1705-1709, 2012.

36.S Iram, K. Parveen, J. Usman, K. Nasir, N. Akhtar, S. Arouj, and I. Ahmad, "Heavy metal tolerance of filamentous fungal strains isolated from soil irrigated with industrial wastewater,' Biologija, vol. 58, no. 3, pp.107-116, 2012.

37.W.C. Leung, M.F. Wong, H.Chua, W. Lo, P.H.F Yu, and C.K. Leung, "Removal and recovery of heavy metals by bacteria isolated from activated sludge treating industrial effluents and municipal waste water," Water science and Technology, vol. 41, pp. 233- 240, 2000.

38.M. Mapolelo, and N. Torto, "Trace enrichment of metal ions in aquatic environments by Saccharomyces cerevisiae," Talanta, vol. 64, pp. 39-47, 2004.

39.N.Yoshida, R. Ikeda, and T. Okuno, "Identification and characterization of heavy metal-resistant unicellular alga isolated from soil and its potential for phytoremediation," Bioresource Technology, vol. 97, pp. 1843-1849, 2006.

40.J. Wang, and C. Chen, "Biosorption of heavy metal by Saccharomyces cerevisiae," Biotechnology Advances, vol. 24, pp. 427-451, 2006.

41.P. A. Maygaonkar, and U. Permeswaran, "Reduction of metallic constituents from distillery effluent by fungi," Bioscience Discovery, vol. 3, no.2, pp.193-196, 2012.

42.P. Hirpara, B. Nikhil, and D. Srinivas, "Bacterial treatment for removal of chromium (VI) containing electroplating waste waters," Indian Journal of Applied Research, vol. 4, no. 6, pp. 436-438, 2014.

43.D.B. Duncan, "Multiple range and multiple F test," Biomerics, vol. 11, pp. 1-42, 1955.

44.J. A. Sayer, S.L. Raggett, and G.M. Gadd, "Solubilization of insoluble metal compounds by soil fungi: development of a screening method for solubilizing ability and metal tolerance," Mycological Research, vol. 99, pp. 987-993, 1995.

45.R. A. Kumar, and P. Riyazudin, "Chromium speciation in a contaminated groundwater: redox processes and temporal variability," Environmental Monitoring and Assessment, vol. 160, pp. 579-591, 2010. 
46.K. Fujii, and S. Fukunaga, "Isolation of highly copper-tolerant fungi from the smelter of the naganobori copper mine, an historic mine in Japan," Journal of Applied Microbiology, vol. 105, pp.1851-1857, 2008.

47.C. K. Shivakumar, B. Thippeswamy, and M. Krishnappa, "Optimization of heavy metals bioaccumulation in Aspergillus niger and Aspergillus flavus," International Journal of Environmental Biology, vol. 4, no. 2, pp. 188-195, 2014.

48.T. Sekova, D.T. odorova, and S. Ganeva, "Removal of heavy metals from industrial wastewater by free and immobilized cells of Aspergillus niger," International Biodeterioration and Biodegradation, vol. 64- pp. 447, 2010.

49.R. Batool, and S. Hasnain, "Cr+6removal by indigenous bacteria in conjunction with different biowaste materlals: an ecofriendly approach," Journal of the Chilean Chemical Society, vol. 59, pp. 2582- 2587, 2014.

50.A. Kumar, B. S. Bisht, and V. D. Joshi, "Bioremediation potential of three acclimated bacteria with reference to heavy metal removal from waste," International journal of Environmental Sciences, vol. 2, no. 2, pp. 896-908, 2011.

51.S. Jha, R. Chauhan, and S.N. Dikshit, "Fungal biomass as biosorbent for removal of heavy metal from industrial wastewater effluent," Asian Journal of Plant Sciences, vol. 13, no. 2, pp. 39-97, 2014.

52.R. Marandi, F. D. Ardejani, and H. A. Afshar, "Biosorption of Lead (II) and Zinc (II) ions by pre-treated biomass of Phanerochaete chrysosporium," International Journal of Mining and Environmental Issues, vol. 1, no. 1, pp. 9-16, 2010.

53.F. Ekmekyapar, A. Aslan, Y. K Bayhan, and A. Cakici, "Biosorption of copper (II) by non-living lichen biomass of Cladonia rangiformis hoffm," Journal of Hazardous Materials, vol. 137, pp. 293-298, 2006.

54.K. A. Zaied, H.N. Abd El- Mageed, E.A. Fayzalla, A.E. Sharief, and A.A. Zehry, "Enhancement biosorption of heavy metals from factory effluents via recombinants induced in yeast and bacteria," Australian Journal of Basic and Applied Sciences, vol. 2, no. 3, pp. 701-717, 2008.

55.M. J. Rani, B. Hemambika, J. Hemapriya, and V. R. Kannan, "Comparative assessment of heavy metal removal by immobilized and dead bacterial cells: A biosorption approach," African Journal of Environmental Science and Technology, vol. 4, no. 2, pp. 077-083, 2010.

56.R. M. Karakagh, M. Chorom, H. Motamedi, Y. K. Kalkhajeh, and S. Oustan, "Biosorption of Cd and Ni by inactivated bacteria isolated from agricultural soil treated with sewage sludge," Hydrobiology and Ecohydrology, vol. 12, no. 3, pp. 191-198, 2012. 